\title{
Deactivation and Characterization of SCR Catalysts Used in Municipal Waste Incineration Applications
}

\author{
Jan G. M. Brandin ${ }^{1}$ C. U. Ingemar Odenbrand ${ }^{2}$
}

Received: 6 July 2017 / Accepted: 17 October 2017 / Published online: 6 November 2017

(c) The Author(s) 2017. This article is an open access publication

\begin{abstract}
Catalysts used for selective catalytic reduction were deactivated for various times in a slipstream from a municipal solid waste incineration plant and then characterized. The activity for $\mathrm{NO}$ reduction with $\mathrm{NH}_{3}$ was measured. The Brunauer-Emmett-Teller surface areas were determined by $\mathrm{N}_{2}$ adsorption from which the pore size distributions in the mesopore region were obtained. Micropore areas and volumes were also obtained. The composition of fresh and deactivated catalysts as well as fly ash was determined by atomic absorption spectroscopy and scanning electron microscopy with energy dispersive X-ray analysis. The
\end{abstract}

changes in surface area ( $8 \%$ decrease in BET surface area over $2311 \mathrm{~h}$ ) and pore structure were small, while the change in activity was considerable. The apparent pre-exponential factor was $1.63 \times 10^{5}(1 / \mathrm{min})$ in the most deactivated catalyst, compared to $2.65 \times 10^{6}(1 / \mathrm{min})$ in the fresh catalyst, i.e. a reduction of $94 \%$. The apparent activation energy for the fresh catalyst was $40 \mathrm{~kJ} / \mathrm{mol}$, decreasing to $27 \mathrm{~kJ} / \mathrm{mol}$ with increasing deactivation. Characterization showed that catalytic poisoning is mainly due to decreased acidity of the catalyst caused due to increasing amounts of $\mathrm{Na}$ and $\mathrm{K}$.

Jan G. M. Brandin

Jan.Brandin@1nu.se

1 Department of Built Environment \& Energy Technology, Linnaeus University, SE-351 46 Växjö, Sweden

2 Department of Chemical Engineering, Lund University, P.O. Box 124, SE-221 00 Lund, Sweden 


\section{Graphical Abstract}

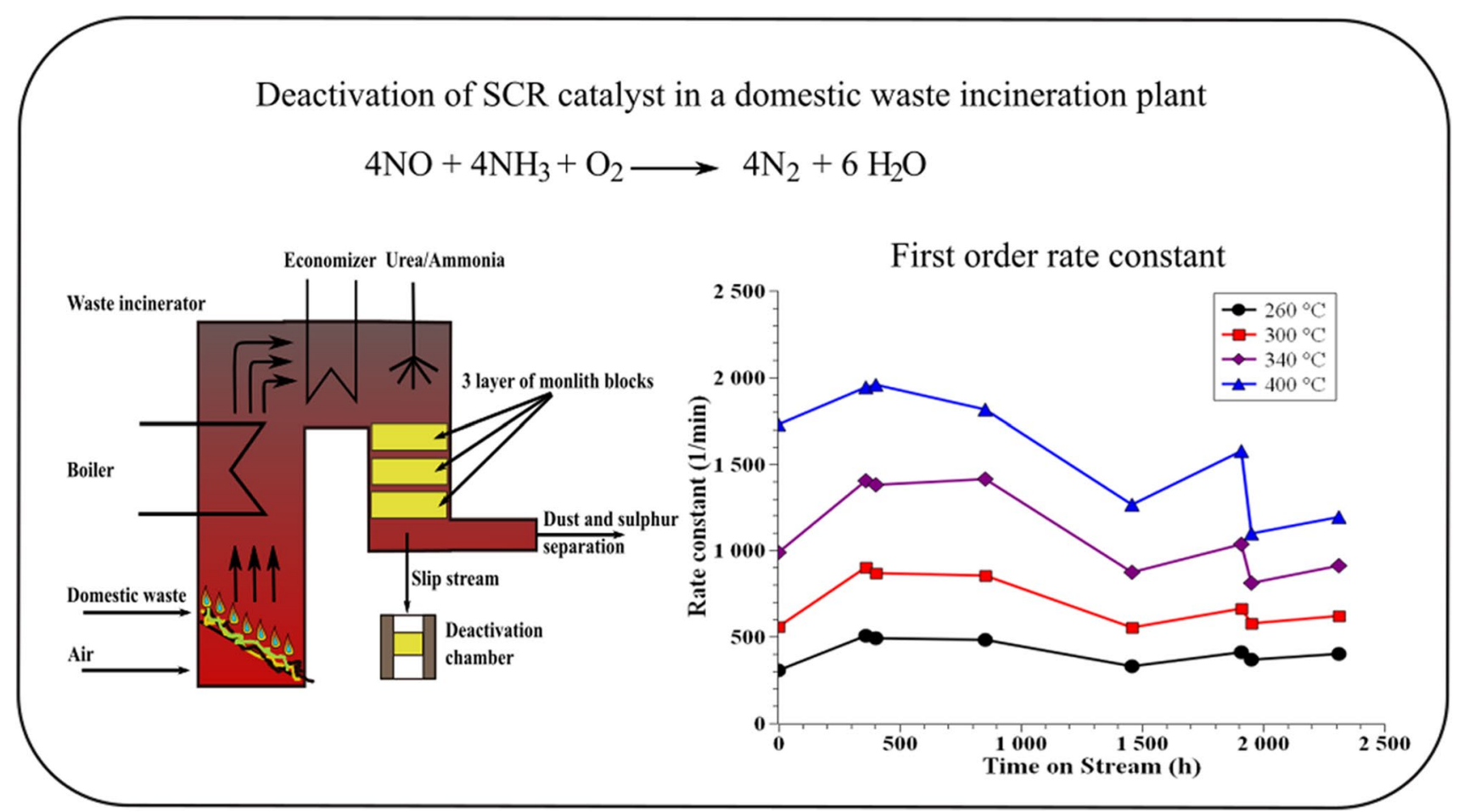

Keywords Deactivation - Characterization $\cdot$ SCR catalysts $\cdot$ Municipal solid waste incineration

\section{Introduction}

In a recent study, selective catalytic reduction (SCR) was compared to selective non-catalytic reduction (SNCR) for the reduction of nitrogen oxides $\left(\mathrm{NO}_{\mathrm{x}}\right)$ [1]. The authors reported that in order to reduce the $\mathrm{NO}_{\mathrm{x}}$ level emitted by municipal waste incineration (MSWI) plants to $100 \mathrm{mg} /$ $\mathrm{Nm}^{3} \mathrm{SCR}$ it may be necessary to replace SNCR with SCR. In our view, in new installations, the catalyst should be placed after the boiler in a high-dust position. However, deactivation of the catalyst by compounds in the fly ash will then become a serious problem. Fly ash contains many potentially poisonous compounds, of which alkali metals are of the greatest concern [2-4]. These will cause deactivation of the catalysts, by blocking the Brønsted acid sites, as in the case of the burning forest residues $[3,5]$. In a previous study, we investigated the effect of impregnation with lead nitrate on the activity of SCR catalysts, and found it to be large [6]. We have also reported on the deactivation of SCR catalysts after use for $2000 \mathrm{~h}$ in the treatment of flue gases from a MSWI plant [7]. In this latter study, alkali metals and some other metals were shown to deactivate the catalyst to a high degree. The components of fly ash determine the degree of the deactivation of the catalyst.

A number of studies have been published recently regarding the fly ash from MSWI plants [8-11]. Some are concerned with the stabilization of the ash for use in construction works [8], while others deal with the recovery of, e.g., $\mathrm{Zn}$ from the ash [9], tailoring catalyst for simultaneous abatement of polychlorinated dibenzodioxins (PCDD) and NOx [10] or developing a better catalyst for MSWI applications [11]. There is also a vast amount of information on the deactivation of SCR catalysts in general [12-20]. Li et al. [12] presented a review on the topic in 2016, where they discussed the deactivation and possible regeneration of the catalyst. The deactivating compounds mentioned are alkali metals, alkaline earth metals, $\mathrm{SO}_{2}, \mathrm{HCl}, \mathrm{P}_{2} \mathrm{O}_{5}$ and heavy metals such as $\mathrm{Pb}, \mathrm{As}$, and $\mathrm{Zn}$. Alkali metals deactivate catalysts by neutralizing the Brønsted acid sites. Alkaline earth metals cause moderate deactivation, compared to $\mathrm{K}$ and $\mathrm{Na} . \mathrm{SO}_{2}$ has a dual effect, causing deactivation by ammonium bisulphates at low temperatures, and activation at temperatures between 350 and $450{ }^{\circ} \mathrm{C}$. Activation is caused by formation of sulphate groups on the $\mathrm{TiO}_{2}$ support. The possible deactivating effect of $\mathrm{CaSO}_{4}$ is also noted. $\mathrm{Pb}$ has been reported to cause serious catalytic poisoning by either chemical reaction, or by the introduction of a barrier between the 
gas phase and the active sites. $\mathrm{Zn}$ has been found to cause about the same degree of deactivation as $\mathrm{K}$. Wu et al. [13] found strong deactivation (a $65 \%$ decrease in conversion) in the presence of both $\mathrm{K}$ and $\mathrm{Cl}$ between 300 and $400{ }^{\circ} \mathrm{C}$. Lei et al. [18] studied different deactivation methods and their effects when using $\mathrm{KCl}$ as deactivating agent. The three methods studied were: wet impregnation, solid diffusion and vapour deposition. The method chosen was found to mainly effect the rate of deactivation. The observed decay rates were 1.9, 3.0 and 12.3\%/day for wet impregnation, solid diffusion and vapour deposition, respectively.

In this study, we have determined which of the components of the fly ash from a MSWI plant deactivate a commercial SCR catalyst. The activity of the SCR reaction was correlated to the contents of the elements in the catalyst, measured by atomic absorption spectroscopy (AAS). The thermal stability of the fly ash and the fresh catalyst was studied separately in order to explain the results obtained from the poisoned catalysts.

\section{Methods}

\subsection{Deactivation of the Catalyst}

The type of catalyst studied was a commercial $\mathrm{V}_{2} \mathrm{O}_{5} / \mathrm{WO}_{3}$ on $\mathrm{TiO}_{2}$ catalyst strengthened by silica fibres. The manufacturer cannot be given because of confidentiality agreement. A total of seven 200 -mm long, $150 \mathrm{~mm} \times 150 \mathrm{~mm}$ monoliths with a wall thickness of $1.1 \mathrm{~mm}$ and a pitch of $7.5 \mathrm{~mm}$ were used [7]. Four of them were placed in a deactivation chamber in a slipstream from the main flue gas channel, with gas flowing from top to bottom. The conditions in the deactivation chamber were: temperature $230^{\circ} \mathrm{C}, \mathrm{NO}_{\mathrm{x}} 60 \mathrm{mg} /$ $\mathrm{Nm}^{3}$ and $\mathrm{NH}_{3} 20 \mathrm{mg} / \mathrm{Nm}^{3}$ (45 and $26 \mathrm{ppm}$ respectively), $\mathrm{O}_{2}$ $2 \%$ and space velocity $5000 \mathrm{~h}^{-1}$. $\mathrm{SO}_{2}$ was also present at 50 to $200 \mathrm{ppm}$ [21].

The monoliths were subjected to these conditions for various times. When one monolith was removed, a new one was inserted in its place and placed in the slipstream for a new period of deactivation. This procedure was repeated until seven monoliths had been deactivated for various amounts of time. The deactivated monoliths and a new, unexposed monolith were analysed using the methods described below.

\subsection{Measurement of Catalyst Activity}

The activity of samples taken from the fresh and deactivated monoliths was determined as described previously [6]. Samples (one monolith channel including walls, $60 \mathrm{~mm}$ long) were cut from the front of the full monoliths and tested for activity, for surface area, pore structure and for chemical composition. A Balzer QMG 311 mass spectrometer was used for gas analysis. The temperatures used in the test for activity in the reduction of $\mathrm{NO}$ were from 260 to $400{ }^{\circ} \mathrm{C}$ at $20{ }^{\circ} \mathrm{C}$ intervals, with 40 minutes' equilibration time at each temperature. The gas stream contained about $600 \mathrm{ppm}$ $\mathrm{NO}, 700 \mathrm{ppm} \mathrm{NH}_{3}$, and $2 \% \mathrm{O}_{2}$, with $\mathrm{He}$ as the carrier gas, containing about $3000 \mathrm{ppm}$ Ar which was used as an internal standard. The flow rate was $900 \mathrm{Ncm}^{3} / \mathrm{min}$, the space velocity was $12,800 \mathrm{~h}^{-1}$, and the pressure was kept at around 1.25 bar. The analysis set-up is shown in Fig. 1.

The activity is presented as an apparent rate constant determined from the following equations:

$\mathrm{x}=$ conversion of $\mathrm{NO}=\left(\mathrm{CNO}_{\text {in }}-\mathrm{CNO}_{\text {out }}\right) / \mathrm{CNO}_{\text {in }}$

where $\mathrm{CNO}_{\text {in }}$ is the concentration of $\mathrm{NO}$ in inlet to reactor $\left(\mathrm{mol} / \mathrm{cm}^{3}\right), \mathrm{CNO}_{\text {out }}$ is the concentration of NO in outlet from reactor $\left(\mathrm{mol} / \mathrm{cm}^{3}\right)$.

$\mathrm{r}_{\mathrm{NO}}=$ rate of disappearence of $\mathrm{NO}$

$$
=-\mathrm{k}_{\mathrm{NO}} \times[\mathrm{NO}]^{1} \times\left[\mathrm{NH}_{3}\right]^{0}\left(\mathrm{~mol} / \mathrm{cm}^{3}{ }_{\text {cat }}, \min \right)
$$

$k_{N O}=-F_{N O i n} /\left(C N O_{i n} \times V_{c a t}\right) \times \ln (1-x)\left(\mathrm{cm}^{3}{ }_{\text {gas }} /\left(\mathrm{cm}^{3}\right.\right.$ cat, $\left.\min \right)$

$k_{N O}=k_{N O 0} \times \exp \left(-E_{a} /(R \times T)\right)$

where $\mathrm{k}_{\mathrm{NO}}$ is the first order rate constant $(1 / \mathrm{min})$, based on catalyst volume, $\mathrm{F}_{\mathrm{NOin}}$ is the molar flow of $\mathrm{NO}$ into the reactor $(\mathrm{mol} / \mathrm{min}), \mathrm{k}_{\mathrm{NO} O}$ is the pre-exponential factor $(1 / \mathrm{min})$, $E_{a}$ is the activation energy $(\mathrm{J} / \mathrm{mol}), \mathrm{R}$ is the universal gas constant $(\mathrm{J} / \mathrm{mol} / \mathrm{K})$, $\mathrm{T}$ is the temperature $(\mathrm{K})$.

$\mathrm{V}_{\text {cat }}=\mathrm{L} \times \mathrm{A}_{\text {wall }}=6 \times 0.33=1.98\left(\mathrm{~cm}^{3}\right)$

where $\mathrm{V}_{\text {cat }}$ is the volume of catalyst wall $\left(\mathrm{cm}^{3}\right)$, calculated from the dimensions of the $60 \mathrm{~mm}$ long channel used, $\mathrm{L}$ is the length of the monolith $=6 \mathrm{~cm}$ in the majority of the experiments, $A_{\text {wall }}$ is the cross sectional area of the monolith wall $=0.86^{2}-0.64^{2}=0.33\left(\mathrm{~cm}^{2}\right)$, Area inside

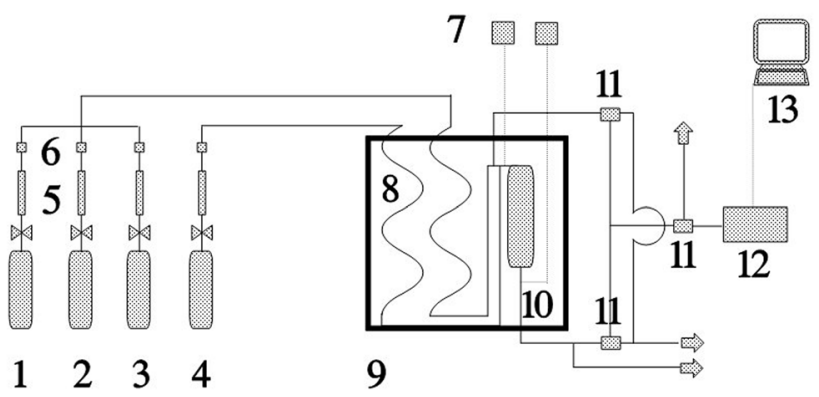

Fig. 1 Experimental set-up used to analyse the activity of the catalyser samples. 1, 2, 3, and 4: Gas cylinders for $\mathrm{He}, \mathrm{O}_{2}, \mathrm{NO}$ and $\mathrm{NH}_{3}$, respectively. 5 Rotameters, 6 Flow regulators, 7 Pressure sensors, 8 Preheating quartz glass tubes, 9 Oven with temperature regulator, 10 Quartz glass reactor, 113 -way valves for selection of gas to the analyser, 12 Mass spectrometer, 13 Computer 
wall $=4 \times 0.64 \times$ length $=15.36\left(\mathrm{~cm}^{2}\right)$, Vol/Area inside wall $=1.98 / 15.36=0.1289(\mathrm{~cm})$.

$\mathrm{rNO}_{\text {obs }}=\mathrm{F}_{\mathrm{NOin}}(\mathrm{mol} / \mathrm{s}) \times \mathrm{x} / \mathrm{V}_{\text {cat }}$

$\mathrm{kmt}$ is the mass transfer coefficient from Sherwood number [22] $(\mathrm{cm} / \mathrm{s})$, Shav is the average Sherwood number $=2.696\left(1+0139 / \mathrm{z}^{\prime}\right)^{0.81}, \mathrm{z}^{\prime}$ is the non-dimensional length $=\mathrm{L} \times \mathrm{D}_{\mathrm{NO}} /\left(\mathrm{dh}^{\wedge} 2 \times \mathrm{u}\right)$

$\mathrm{kmt}=\mathrm{Shav} \times \mathrm{D}_{\mathrm{NO}} / \mathrm{dh}(\mathrm{cm} / \mathrm{s})$

$\mathrm{dh}$ is the hydraulic diameter $=0.64(\mathrm{~cm}), \mathrm{D}_{\mathrm{NO}}$ is the molecular diffusivity of $\mathrm{NO}$ in $\mathrm{He}\left(\mathrm{cm}^{2} / \mathrm{s}\right), \mathrm{D}_{\mathrm{NO}}$ iff is the effective diffusivity of $\mathrm{NO}$ in pores $\left(\mathrm{cm}^{2} / \mathrm{s}\right)$, twall is the wall thickness $=0.11(\mathrm{~cm})$.

The length of the mini-monoliths varied somewhat from sample to sample. Therefore, the measured values of concentrations and monolith length were used in the calculation of the rate constants. To determine the presence of mass and temperature gradients in the catalyst the criteria presented by Ramirez were used [23]. For mass gradients inside the monolith wall we used criterion number 7 :

$\mathrm{rNO}_{\text {obs }} \times \mathrm{twall}^{2} /\left(\mathrm{D}_{\mathrm{NOeff}} \times \mathrm{CNO}_{\text {in }}\right)$

and for external mass transport criterion number 5 was used:

$\mathrm{rNO}_{\text {obs }} /\left(\mathrm{A}_{\text {wall }} / \mathrm{Vol}_{\text {cat }} \times \mathrm{kmt} \times \mathrm{C}_{\mathrm{NOin}}\right)$.

\subsection{Measurements of the Catalyst Composition}

There is a distribution of the poisonous compounds in and on the surface of the monolithic catalyst wall. SEM is used to study the surface of the catalyst but also the penetration of the poisons into the monolith wall. To study the composition of the bulk of the catalyst the surface layer was removed. AAS, which is a more exact method, was used in order to quantify the amount of poisons and determined the content in the whole piece used for analysis.

\subsubsection{Analysis Using AAS}

The equipment used was a GSM atomic absorption spectrometer. The catalyst samples were crushed and finely ground in a mortar. Known weights were dissolved in $25 \mathrm{ml}$ $40 \%$ HF. The solution was diluted with distilled water to the concentration required for analysis. All analyses were performed on duplicate or triplicate samples to reduce the influence of analytical errors. The results given are the mean values of the experimental ones in weight percent (wt\%).

\subsubsection{Analysis Using SEM-EDAX}

The catalyst samples and the fly ash were analysed using a JEOL JSM-840A scanning electron microscope with a Link
AN 10000 energy-dispersive X-ray analyser. Various elements were determined quantitatively on the surface, and in the bulk when a $0.4 \mathrm{~mm}$ layer scraped off the surface. The concentrations of elements across the catalyst wall were also mapped to determine whether there was a concentration gradient. The components of the catalyst: Ti, Si, W, V and $\mathrm{Al}$, were determined as well as the catalyst poisonous compounds. The results are given as atom $\%$.

\subsection{Analysis Using $\mathrm{N}_{2}$ Adsorption}

The surface area and the pore size distribution of fresh and deactivated catalysts as well as the fly ash were determined by physisorption of $\mathrm{N}_{2}$ at $-196{ }^{\circ} \mathrm{C}$. For catalysts, this study of the pore system was performed on a piece of the wall of the monolith using a Micromeritics ASAP 2400 system. Outgassing was performed at $0.04 \mathrm{~mm} \mathrm{Hg}$ and $90^{\circ} \mathrm{C}$ for $1 \mathrm{~h}$ and at $400{ }^{\circ} \mathrm{C}$ for $24 \mathrm{~h}$ to a final pressure of $10^{-3}$ torr before the adsorption study. The BET surface area was calculated as described by Brunauer et al. [24]. The accuracy of this method was better than $1 \%$, according to separate measurements for the experimental conditions used. The mesopore size distribution was calculated using the method described by Barett et al. [25]. The total pore volume is given for pores smaller than $3000 \AA$ A in diameter.

The micropore volume and the micropore surface area were calculated using the t-plot method of Harkins and Jura [26]. Samples of the fresh catalyst were also submitted to sintering for up to $288 \mathrm{~h}$ at $400{ }^{\circ} \mathrm{C}$ to study the stability of this material. To study the melting or removal of poisonous compounds from the deactivated monoliths the degassing temperature, before measurement of surface area, was varied between 100 and $450{ }^{\circ} \mathrm{C}$ in $50{ }^{\circ} \mathrm{C}$ intervals. The degassing was performed for $24 \mathrm{~h}$ at each temperature. The fresh catalyst was also treated at $400{ }^{\circ} \mathrm{C}$ for various lengths of time to study possible sintering.

\section{Results}

\subsection{Fly Ash}

The ash was crushed and freshly ground in a mortar and was dark grey.

\subsubsection{Surface Area and Pore Structure}

The BET surface area (SBET) as well as the micropore surface area (Smicro) are constant at about up to a degassing temperature of $300{ }^{\circ} \mathrm{C}$ after which they decrease sharply (Fig. 2). The BET area decreases from 5.26 to $2.95 \mathrm{~m}^{2} / \mathrm{g}$ between 250 and $400{ }^{\circ} \mathrm{C}$ and does not decrease further at $450{ }^{\circ} \mathrm{C}$, i.e. a decrease of $44 \%$. The micropore area 
Fig. 2 Surface areas of the fly ash as a function of the degassing temperature

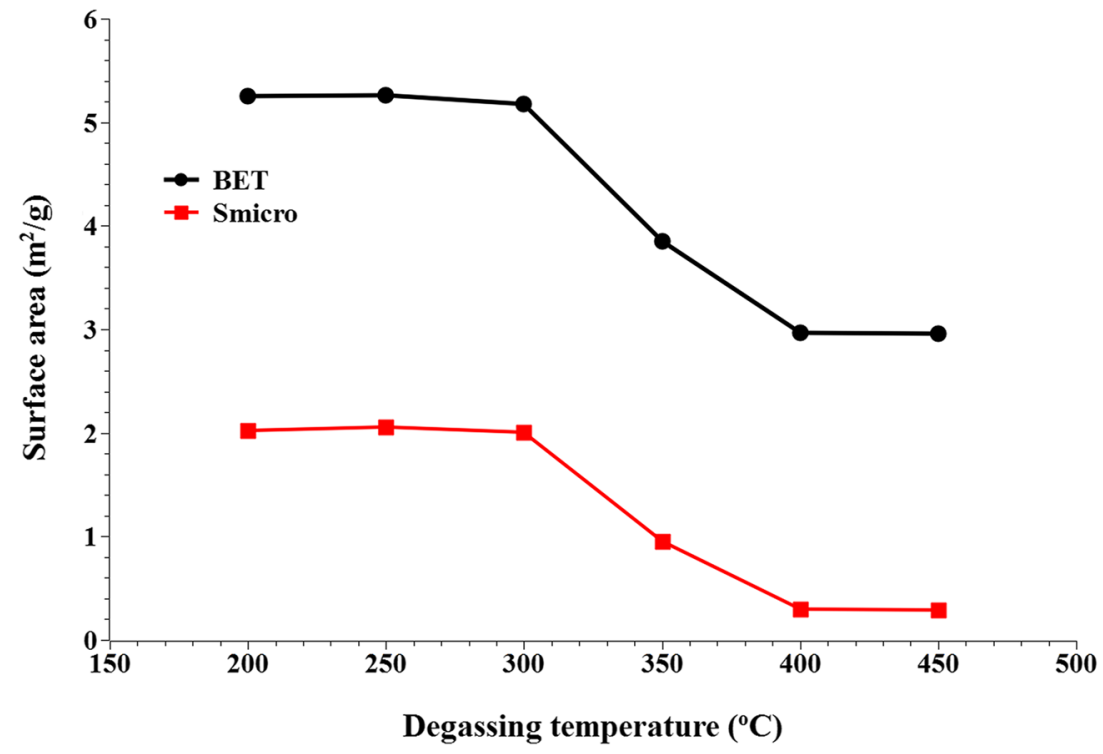

decreased from 2.06 to $0.29 \mathrm{~m}^{2} / \mathrm{g}$, i.e. by $86 \%$. These results indicate that the fly ash contains one or more compounds that decrease access to the micropores above $300{ }^{\circ} \mathrm{C}$.

It can be seen from Fig. 3 that the total pore volume seems to be more or less independent of the degassing temperature. However, the volume of the micropores decreases sharply at temperatures above $300{ }^{\circ} \mathrm{C}$ from 9 to $1.2 \times 10^{-4} \mathrm{~cm}^{3} / \mathrm{g}$, i.e. by $87 \%$, similar to the decrease in the micropore surface area.

Figure 4 shows the cumulative surface area (Scum) distribution for small mesopores (down to $17 \AA$ ) at various degassing temperatures. The curves for 150,200 and $300{ }^{\circ} \mathrm{C}$ show very similar behaviour. At 350,400 and $450{ }^{\circ} \mathrm{C}$ the cumulative surface area (Scum) is constant below $35 \AA$, meaning that only a small fraction of pores is in the region 17-35 $\AA$. At diameters above $35 \AA$ all the curves overlap.

\subsubsection{Chemical Composition of the Fly Ash}

Fly ash contains many elements known to be poisonous to the catalyst ( $\mathrm{Mg}, \mathrm{K}, \mathrm{Na}, \mathrm{P}, \mathrm{Zn}$ and $\mathrm{Ca}$ ) [4]. It can be seen from Table 1 that some components are evenly distributed (small standard deviations) over the surface ( $\mathrm{Mg}, \mathrm{Na}, \mathrm{K}$ and $\mathrm{Si}$ ) while others vary between sampling points $(\mathrm{P}, \mathrm{Ti}, \mathrm{Fe}$, $\mathrm{Zn}, \mathrm{Al}, \mathrm{S}, \mathrm{Cl}$ and $\mathrm{Ca}$ ). Large amounts of $\mathrm{Cl}$ and $\mathrm{S}$ were found in the fly ash. However, $\mathrm{Pb}$ was not detected, which is strange as it was detected in poisoned catalysts using AAS (see below).
Fig. 3 Total volume and micropore volume of the fly ash as a function of the degassing temperature

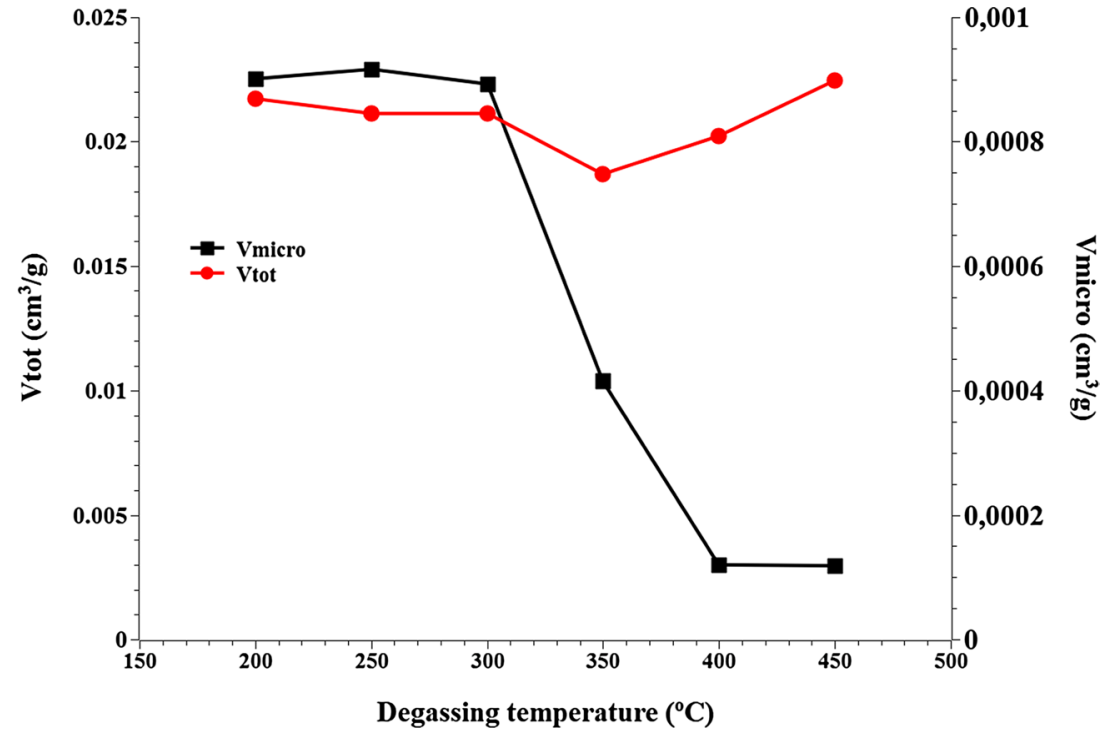


Fig. 4 Cumulative pore area distribution (Scum) for fly ash

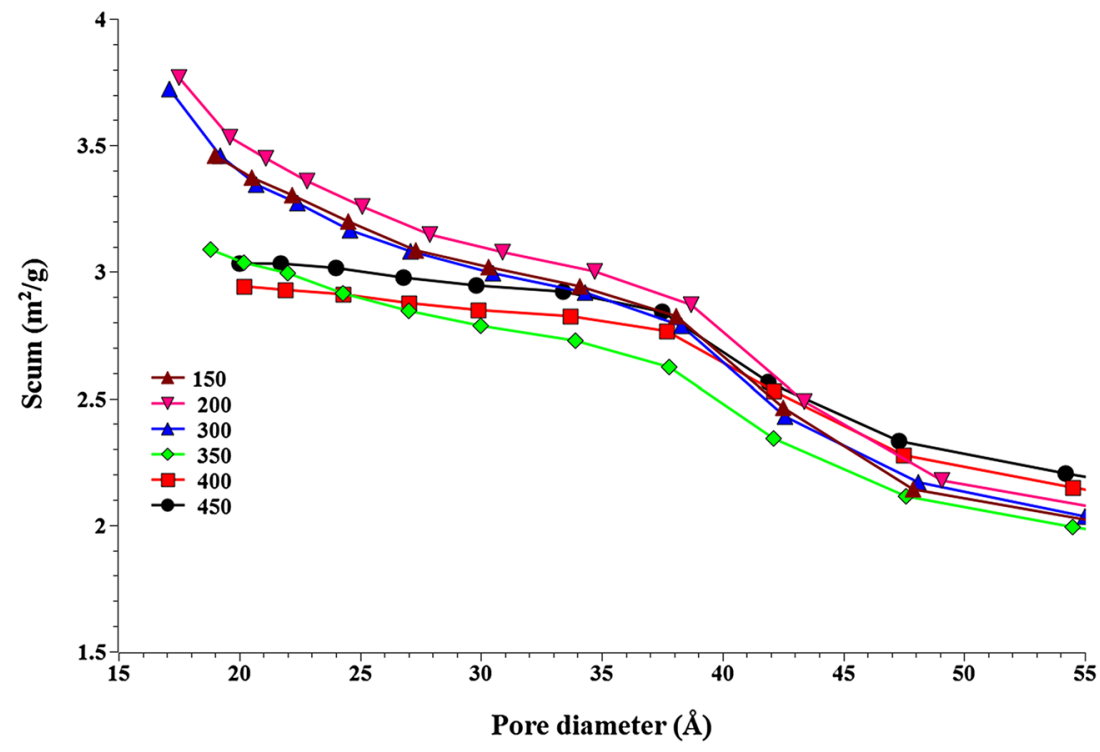

Table 1 Composition (atom \%) on two points on the surface of the fly ash as determined by SEM-EDAX

\begin{tabular}{lcccc}
\hline Element & Sample 1 & Sample 2 & Mean & SD \\
\hline $\mathrm{P}$ & 1.02 & 2.25 & 1.64 & 0.50 \\
$\mathrm{Ti}$ & 1.63 & 2.70 & 2.16 & 0.44 \\
$\mathrm{Fe}$ & 2.33 & 1.79 & 2.06 & 0.22 \\
$\mathrm{Mg}$ & 3.85 & 3.03 & 3.44 & 0.33 \\
$\mathrm{Zn}$ & 3.87 & 6.53 & 5.20 & 1.09 \\
$\mathrm{Na}$ & 3.98 & 4.43 & 4.21 & 0.18 \\
$\mathrm{~K}$ & 4.27 & 4.49 & 4.38 & 0.09 \\
$\mathrm{Al}$ & 9.20 & 11.93 & 10.56 & 1.11 \\
$\mathrm{~S}$ & 11.87 & 8.95 & 10.41 & 1.19 \\
$\mathrm{Cl}$ & 12.22 & 11.32 & 11.77 & 0.37 \\
$\mathrm{Si}$ & 14.91 & 14.83 & 14.87 & 0.03 \\
$\mathrm{Ca}$ & 30.87 & 27.77 & 29.32 & 1.27 \\
\hline
\end{tabular}

S.D. standard deviation

Table 2 Effect of degassing temperature on pore structure of the fresh catalyst degassed for $24 \mathrm{~h}$ at the given temperature

\subsection{Fresh Catalyst}

\subsubsection{Surface Area and Pore Structure}

Table 2 presents the effect of degassing temperature on the pore structure of the fresh catalyst. It can be seen that there is almost a 5\% increase in BET surface area (from 62 to $65 \mathrm{~m}^{2} / \mathrm{g}$ ) when the temperature is increased from 100 to $400{ }^{\circ} \mathrm{C}$ (Table 2). The total pore volume does not seem to be dependent on degassing temperature, and shows a maximum of $0.271 \mathrm{~cm}^{3} / \mathrm{g}$ at $400{ }^{\circ} \mathrm{C}$. The micropores open up increasing the area from 3.1 to $7.5 \mathrm{~m}^{2} / \mathrm{g}$ at $400{ }^{\circ} \mathrm{C}$. At $450{ }^{\circ} \mathrm{C}$ the value falls to $6.3 \mathrm{~m}^{2} / \mathrm{g}$ indicating instability at this high temperature (as discussed below). The micropore volume increases up to $400{ }^{\circ} \mathrm{C}$ and then decreases at $450{ }^{\circ} \mathrm{C}$. The micropore volumes are very small compared to the total pore volumes, being between 0.44 and $1.03 \%$ of the total pore volume. The average pore diameter increases from 148 to $180 \AA$ as the temperature increases.

The accuracy of the measurements of the BET surface area and the micropore surface area was determined by

\begin{tabular}{lllllc}
\hline $\begin{array}{l}\text { Temperature } \\
\left({ }^{\circ} \mathrm{C}\right)\end{array}$ & SBET $\left(\mathrm{m}^{2} / \mathrm{g}\right)$ & Vtot $\left(\mathrm{cm}^{3} / \mathrm{g}\right)$ & Smicro $\left(\mathrm{m}^{2} / \mathrm{g}\right)$ & Vmicro $\left(\mathrm{cm}^{3} / \mathrm{g}\right)$ & Dpore $(\AA)$ \\
\hline 100 & 62.0 & 0.224 & 3.1 & 0.0010 & 148.1 \\
150 & 62.1 & 0.218 & 4.3 & 0.0015 & 145.6 \\
200 & 63.4 & 0.240 & 5.1 & 0.0018 & 158.7 \\
250 & 64.7 & 0.222 & 6.1 & 0.0023 & 144.9 \\
300 & 63.7 & 0.235 & 6.4 & 0.0024 & 158.8 \\
350 & 65.6 & 0.229 & 6.9 & 0.0026 & 150.7 \\
400 & 65.0 & 0.271 & 7.5 & 0.0028 & 179.7 \\
450 & 64.9 & 0.269 & 6.3 & 0.0023 & 177.9 \\
\hline
\end{tabular}


measuring four samples of the reference material degassed at $400{ }^{\circ} \mathrm{C}$. The values obtained were $\pm 1 \%$ for the BET surface area and $\pm 5 \%$ for the micropore volume.

\subsubsection{Chemical Composition}

The results of the elemental analysis of the fresh catalyst using SEM-EDAX and AAS are given in Table 3. The most abundant element in the surface as in the bulk is Ti at 87 atom $\%$ as expected since $\mathrm{TiO}_{2}$ is the catalyst support. The silicon (5 and $4 \%$ respectively) probably arises from silica in the glass fibres identified by SEM. Wolfram is present at 3 atom $\%$ and is a common component of modern SCR catalysts. Vanadium is present at 1.9 and 1.6 atom \% in the

Table 3 Results of SEM-EDAX analysis (atom \%) and AAS (wt\%) of the fresh catalyst

\begin{tabular}{lllc}
\hline Element & Surface & Bulk & By AAS \\
\hline $\mathrm{Al}$ & 1.27 & 1.60 & 0.53 \\
$\mathrm{Si}$ & 5.27 & 4.29 & 8.61 \\
$\mathrm{~W}$ & 2.92 & 3.02 & 7.00 \\
$\mathrm{Ti}$ & 86.41 & 87.57 & 49.00 \\
$\mathrm{~V}$ & 1.93 & 1.57 & 0.535 \\
$\mathrm{~S}$ & 1.52 & 1.42 & \\
$\mathrm{Cl}$ & 0 & 0 & \\
$\mathrm{Ca}$ & 0.62 & 0.54 & 0.17 \\
$\mathrm{Na}$ & & & 0.026 \\
$\mathrm{~K}$ & & & 0.056 \\
$\mathrm{Zn}$ & & & 0.008 \\
$\mathrm{Fe}$ & & & 0.137 \\
$\mathrm{~Pb}$ & 99.94 & 100.01 & 0.011 \\
$\mathrm{Total}$ & & & 66.08 \\
\hline
\end{tabular}

surface and in the bulk. The atomic ratio between aluminium and calcium is about 2 in the surface, and closer to 3 in the bulk for the fresh catalyst. This could indicate that $\mathrm{Ca}$-aluminate cement (forming $\mathrm{CaAl}_{2} \mathrm{O}_{4}$ ) has been used as a binder in the catalyst, and the composition may vary somewhat depending on the mixing in the manufacture of the catalyst.

The values measured using AAS, recalculated to give the percent by weight and assuming oxides, were $0.91 \%$ vanadium pentoxide, $8.45 \%$ tungsten trioxide on $78.27 \%$ titanium dioxide and $11.03 \%$ silica as mechanical reinforcement. A binder, $\mathrm{CaAl}_{2} \mathrm{O}_{4}$, is present at a level of about $1.03 \%$. AAS analysis also showed the presence of iron (probably hematite) at below $0.2 \%$. Minor amounts of $\mathrm{Na}$ and $\mathrm{K}$ oxides were also found, together constituting about $0.1 \%$.

\subsubsection{Stability of the Fresh Catalyst at $400{ }^{\circ} \mathrm{C}$}

All samples have been degassed at $400{ }^{\circ} \mathrm{C}$ for $24 \mathrm{~h}$ before the start of the sintering process. The sintering was performed in an oven in air at $400{ }^{\circ} \mathrm{C}$ for the time given. It is obvious that there is a, after some instabilities below $72 \mathrm{~h}$, decrease of BET surface area from 69.9 to $62.1 \mathrm{~m}^{2} / \mathrm{g}$ (by $7.8 \mathrm{~m}^{2} / \mathrm{g}$ ) after $288 \mathrm{~h}$ (Fig. 5). The accuracy in the surface area is better than $1 \%$ so the drop $(11.1 \%)$ is noticeable. The area in the pores smaller than $17 \AA$ (Smicro) drops from a value of $8.9-2.1 \mathrm{~m}^{2} / \mathrm{g}$ (by $6.8 \mathrm{~m}^{2} / \mathrm{g}$ ) at $288 \mathrm{~h}$. Thus, most of the decrease in area takes place in the smallest pores.

We studied the mesopore size distribution in order to find a correlation to the loss in surface area. There is no systematic difference in the mesopore size distribution for the sintered samples (not shown here).

It can be seen from Fig. 6 that the total pore volume increases very little, from $0.270 \mathrm{~cm}^{3} / \mathrm{g}$ before sintering, to $0.277 \mathrm{~cm}^{3} / \mathrm{g}$ after sintering for $288 \mathrm{~h}$. However, there is some
Fig. 5 The effect of sintering time on the pore surface area of the fresh catalyst

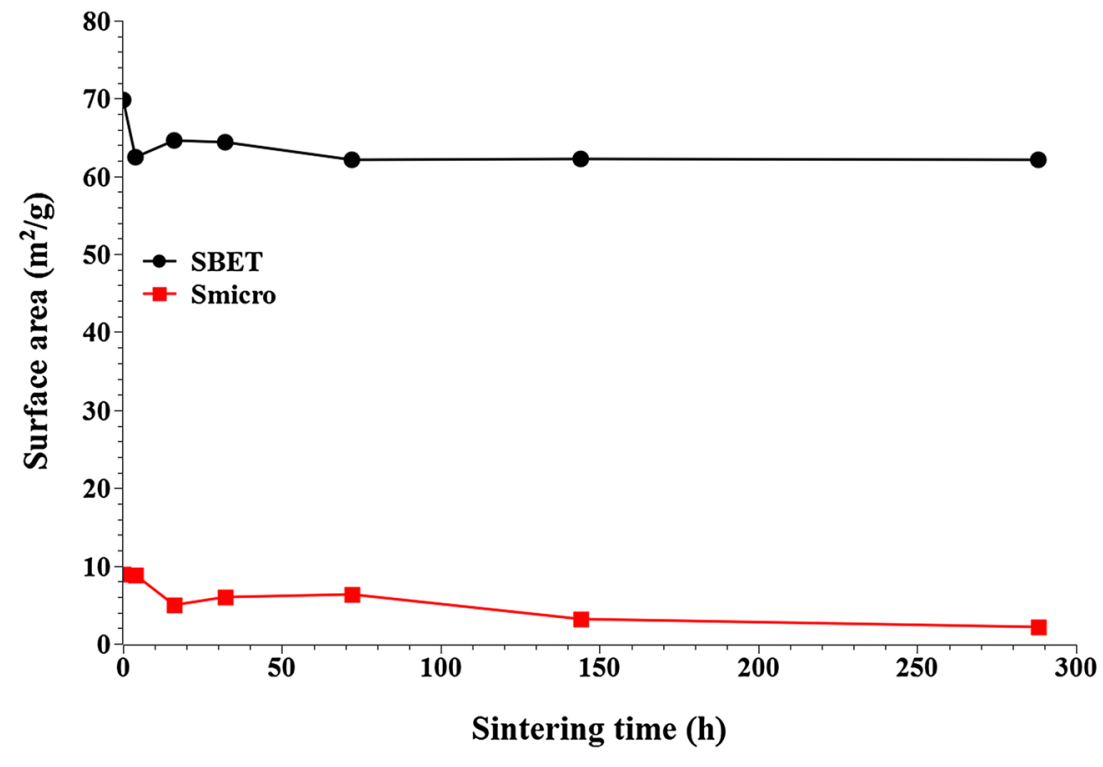


Fig. 6 The effect of sintering time on the pore volume of the fresh catalyst

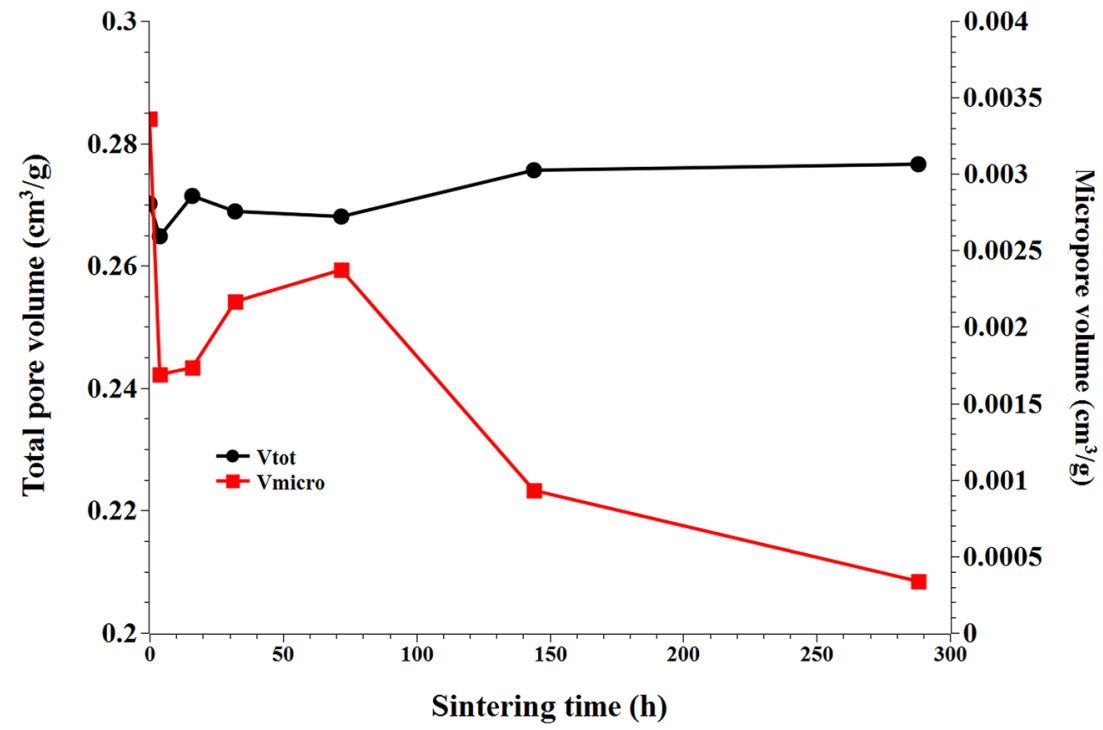

Table 4 The effect of deactivation time on surface area and pore structure

\begin{tabular}{lllll}
\hline $\begin{array}{l}\text { Deactivation } \\
\text { time }(\mathrm{h})\end{array}$ & $\begin{array}{l}\text { SBET } \\
\left(\mathrm{m}^{2} / \mathrm{g}\right)\end{array}$ & $\begin{array}{l}\text { Vtot } \\
\left(\mathrm{m}^{2} / \mathrm{g}\right)\end{array}$ & $\begin{array}{l}\text { Smicro } \\
\left(\mathrm{cm}^{3} / \mathrm{g}\right)\end{array}$ & $\begin{array}{l}\text { Vmicro } \\
\left(\mathrm{cm}^{3} / \mathrm{g}\right)\end{array}$ \\
\hline 0 & 65.0 & 0.2684 & 7.5 & 0.0028 \\
360 & 62.4 & 0.2742 & 2.9 & 0.0008 \\
403 & 62.4 & 0.2647 & 1.7 & 0.0002 \\
853 & 63.1 & 0.2680 & 4.3 & 0.0015 \\
1458 & 63.1 & - & 4.6 & 0.0016 \\
1908 & 58.6 & - & 3.7 & 0.0014 \\
1951 & 60.4 & - & 4.3 & 0.0016 \\
2311 & 60.0 & - & 3.5 & 0.0010 \\
\hline
\end{tabular}

instability in the data at sintering times below $72 \mathrm{~h}$, similar to that seen in Fig. 5. In contrast, the micropore volume decreased from 0.0034 before sintering to $0.0017 \mathrm{~cm}^{3} / \mathrm{g}$ after $4 \mathrm{~h}$, after which it increased to $0.0024 \mathrm{~cm}^{3} / \mathrm{g}$ at $72 \mathrm{~h}$. The final micropore volume after $288 \mathrm{~h}$ was $0.0003 \mathrm{~cm}^{3} / \mathrm{g}$, which corresponds to a $91 \%$ decrease compared with the fresh material.

\subsection{Deactivated Catalysts}

\subsubsection{Surface Area and Pore Structure}

The deactivated samples have BET surface areas, when degassed at $400{ }^{\circ} \mathrm{C}$ for $24 \mathrm{~h}$, which decrease with deactivation time (Table 4). The decrease is 65 to $60 \mathrm{~m}^{2} / \mathrm{g}$ (about $8 \%$ ) over $2311 \mathrm{~h}$. The total pore volume remains unchanged at $0.27 \mathrm{~cm}^{3} / \mathrm{g}$ independent on deactivation time. There is a large decrease in micropore surface area from 7.5 to $1.7 \mathrm{~m}^{2} / \mathrm{g}$ for the sample used for $403 \mathrm{~h}$. At longer times of exposure, the surface area remains constant at $4.1 \mathrm{~m}^{2} / \mathrm{g}$ with a standard deviation of $0.5 \mathrm{~m}^{2} / \mathrm{g}$, which is within the accuracy of these measurements. Thus the drop in micro pore surface area is $45 \%$.

There is an increase in the micropore volume for the fresh catalyst at increasing degassing temperatures as could be expected as water is removed from the small pores (not shown here). After an initial drop of micropore volume from $0.0028 \mathrm{~cm}^{3} / \mathrm{g}$ by $71 \%$ during the first $360 \mathrm{~h}$ there seems to be an almost constant value of $0.0014 \mathrm{~cm}^{3} / \mathrm{g}$ with a standard deviation of $0.0002 \mathrm{~cm}^{3} / \mathrm{g}$ at longer times i.e. a final drop of $50 \%$.

From studies of the pore size distribution (not shown here), there is no difference between the fresh catalyst and the catalyst used for $2311 \mathrm{~h}$ in the mesopore region from 17 to $500 \AA$ A pore diameter.

\subsubsection{Chemical Composition}

The contents of $\mathrm{Na}, \mathrm{K}, \mathrm{Zn}, \mathrm{Fe}, \mathrm{Ca}$ and $\mathrm{Pb}$ were measured by AAS, and the results are shown in Figs. 7 and 8.

The two alkali metals, $\mathrm{Na}$ and $\mathrm{K}$, and $\mathrm{Zn}$ showed a linear increase with deactivation time, reaching contents of 0.20 , 0.26 and $0.36 \mathrm{wt} \%$, respectively (Fig. 7). It should be noted that these values represent the average contents of these metals as the whole wall of the monolith was dissolved before analysis by AAS.

Figure 8 shows the corresponding results for $\mathrm{Ca}, \mathrm{Pb}$ and $\mathrm{Fe}$.

The contents of $\mathrm{Ca}$ and $\mathrm{Pb}$ vary dramatically over time (Fig. 8). The maximal value for $\mathrm{Ca}$ is about $0.9 \mathrm{wt} \%$, while the highest values for $\mathrm{Pb}$ range from about $0.2-0.3 \mathrm{wt} \%$. The fresh catalyst contained some $\mathrm{Ca}(0.17 \mathrm{wt} \%)$ and only very little $(0.011 \mathrm{wt} \%) \mathrm{Pb}$. The content of Fe decreased slightly 
Fig. 7 Contents of $\mathrm{Na}, \mathrm{K}, \mathrm{Zn}$, measured by AAS in deactivated catalysts, as a function of exposure time
Fig. 8 Content of $\mathrm{Ca}, \mathrm{Pb}$ and $\mathrm{Fe}$, measured by AAS, in deactivated catalysts as a function of exposure time
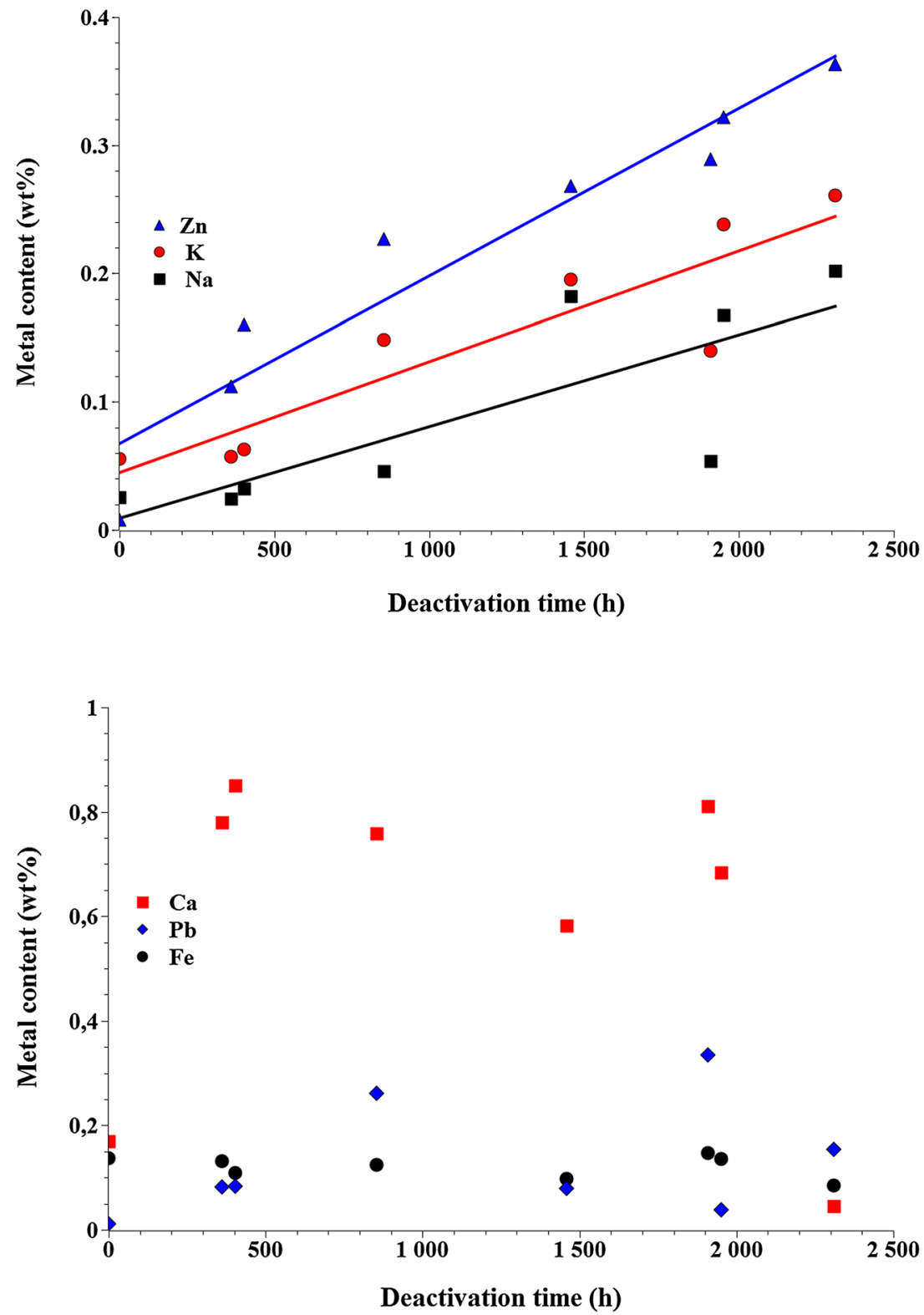

with exposure time from 0 to $2311 \mathrm{~h}$, its maximum being $0.15 \mathrm{wt} \%$.

The results of the SEM-EDAX analysis of two different areas of the catalyst are given in Table 5 .

SEM-EDAX analysis of the sample exposed for $1908 \mathrm{~h}$ showed that the bulk of the catalyst (after the top $0.4 \mathrm{~mm}$ had been removed) did not contain any $\mathrm{Pb}, \mathrm{Zn}$ or $\mathrm{Cl}$, and only small amounts of $\mathrm{Ca}$ and $\mathrm{S}$ (Table 5). The components on the outer surface of the catalyst must thus arise from the fly ash. $\mathrm{Ca}, \mathrm{Pb}$ and $\mathrm{S}$ are also largely the result of exposure to the fly ash. The composition varies considerably between the two points of the surface which were analysed, especially in the cases of $\mathrm{Pb}$ and $\mathrm{Ca}$. Surface 1 is much more contaminated, while the amounts of the catalyst components $\mathrm{V}, \mathrm{W}$ and $\mathrm{Ti}$ are much lower than in the bulk. $\mathrm{V}$ varies from 0.31
Table 5 Results of SEM-EDAX analysis on two points on the surface and in the bulk of the catalyst used for $1908 \mathrm{~h}$ (atom \%)

\begin{tabular}{llcll}
\hline Element & Surface 1 & Surface 2 & Bulk 1 & Bulk 2 \\
\hline $\mathrm{Al}$ & 2.04 & 1.29 & 0.98 & 1.27 \\
$\mathrm{Si}$ & 5.60 & 4.15 & 4.81 & 4.42 \\
$\mathrm{~W}$ & 0 & 2.38 & 3.09 & 3.37 \\
$\mathrm{Ti}$ & 39.52 & 63.23 & 86.76 & 86.49 \\
$\mathrm{~V}$ & 0.31 & 1.20 & 1.46 & 1.62 \\
$\mathrm{~S}$ & 24.46 & 12.80 & 2.43 & 2.34 \\
$\mathrm{Cl}$ & 0.98 & 0.35 & 0 & 0 \\
$\mathrm{Ca}$ & 7.41 & 2.42 & 0.46 & 0.49 \\
$\mathrm{Zn}$ & 4.62 & 4.27 & 0 & 0 \\
$\mathrm{~Pb}$ & 15.06 & 7.90 & 0 & 0 \\
$\mathrm{Total}$ & 100.00 & 99.99 & 99.99 & 100.00 \\
\hline
\end{tabular}


atom $\%$ on Surface 1, to $1.20 \%$ on Surface 2. The amounts of $\mathrm{V}, \mathrm{W}$ and Ti are very similar in the two bulk samples. It can thus be concluded that layers of sulphates and chlorides of $\mathrm{Pb}, \mathrm{Ca}$ and $\mathrm{Zn}$ may cover the sample exposed to flue gases/ fly ash for $1908 \mathrm{~h}$.

Figure 9 shows the ratios of various metals to $\mathrm{V}$ on the surface of the catalyst as a function of exposure time. The maximal coverage (Me/V) for each metal, after $2311 \mathrm{~h}$ deactivation, was 0.84 for $\mathrm{Na}, 0.64$ for $\mathrm{K}$ and 0.53 for $\mathrm{Zn}$.

The data for each metal were fitted to a straight line.

Table 6 gives the values of the parameters, intercept and slope, with $95 \%$ confidence intervals, for the linear fits of metal coverage presented in Fig. 9, together with the coefficients of determination $\left(R^{2}\right)$ for the fits. The value of $R^{2}$ for the $\mathrm{Na} / \mathrm{V}$ data was quite low, so the correlation coefficients, $\mathrm{R}$, were tested using a $t$ test. All the correlations were found to be significant at the $95 \%$ level. The coverage rates, given by the slopes of the fits, are similar for all three metals, taking the $95 \%$ confidence interval into account.

\subsection{Catalyst Activity}

\subsubsection{Activity of the Fresh Catalyst After Sintering}

The rate constants for the fresh and sintered catalysts increased in a regular fashion with temperature, as expected (data not shown). The apparent activation energy of the sintered samples was 33-34 kJ/mol, compared with $35.5 \mathrm{~kJ} /$ mol for the non-sintered samples. The pre-exponential factor decreased from $1.35 \times 10^{6} 1 / \mathrm{min}$ to about $8 \mathrm{e} \times 10^{5} 1 /$ $\min$ after $32 \mathrm{~h}$ sintering, and then remained constant. The decrease in the pre-exponential factor is $40 \%$.
Table 6 The parameters obtained from linear regression of the metal coverage $(\mathrm{Me} / \mathrm{V})$ vs time data

\begin{tabular}{lcclll}
\hline Metal ratio & $\begin{array}{l}\text { Intercept } \\
\left(10^{2}\right)\end{array}$ & $\pm\left(10^{2}\right)$ & $\begin{array}{l}\text { Slope } \\
\left(10^{4} 1 / \mathrm{h}\right)\end{array}$ & $\pm\left(10^{4} 1 / \mathrm{h}\right)$ & $\mathrm{R}^{2}$ \\
\hline $\mathrm{Na} / \mathrm{V}$ & 3.73 & 12.8 & 2.96 & 0.91 & 0.64 \\
$\mathrm{~K} / \mathrm{V}$ & 10.94 & 5.46 & 2.10 & 0.39 & 0.83 \\
$\mathrm{Zn} / \mathrm{V}$ & 9.83 & 3.35 & 1.94 & 0.24 & 0.91 \\
\hline
\end{tabular}

\subsubsection{Activity of the Deactivated Catalysts}

The catalysts have been exposed to flue gases from 36 to $2311 \mathrm{~h}$. The apparent rate constants have been measured and the results are given in Fig. 10.

It can be seen from Fig. 10 that the rate constants vary with exposure time. In our previous study [7], we found parallel processes of deactivation by metals ( $\mathrm{Na}, \mathrm{K}$ and $\mathrm{Zn}$ ) and activation by sulphate groups created on the catalyst surface. The initial increase in the rate constant is due to sulphation. The rate constant reaches a maximum sometime between 403 and $853 \mathrm{~h}$ exposure. The pattern of increase and decrease was similar for all the temperatures investigated. However, the smallest rate constant occurs at different times for different temperatures. At $260{ }^{\circ} \mathrm{C}$ the minimum is at $1458 \mathrm{~h}$, while at $400^{\circ} \mathrm{C}$ it is at $1951 \mathrm{~h}$. The value of the rate constant for the catalyst deactivated for $1908 \mathrm{~h}$ deviates from the expected value. It is much higher than the rate constant for the sample deactivated for $1951 \mathrm{~h}$, especially at the highest temperature. The cause will be discussed below.

Activation energies were determined in the temperature range 260 to $340{ }^{\circ} \mathrm{C}$ (from plots of $\ln (\mathrm{k})$ vs. $1 / \mathrm{T}$ ) and are shown in Fig. 11 for all catalysts.
Fig. 9 The increase in coverage of the $\mathrm{V}$ atoms, with the metals $\mathrm{Na}, \mathrm{K}$ and $\mathrm{Zn}(\mathrm{Me} / \mathrm{V}$ atom ratio), as a function of exposure time

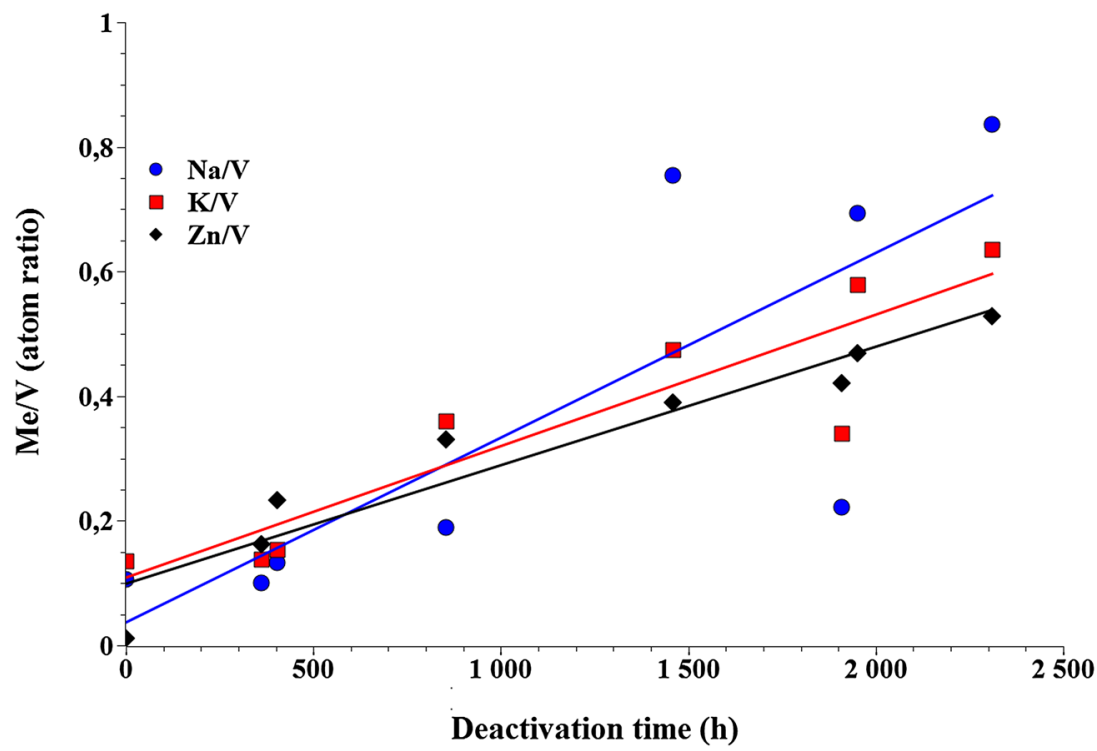


Fig. 10 The effect of exposure time on the rate constant at different temperatures
Fig. 11 The dependence of the activation energy on the $\mathrm{K} / \mathrm{V}$ ratio for all the catalysts
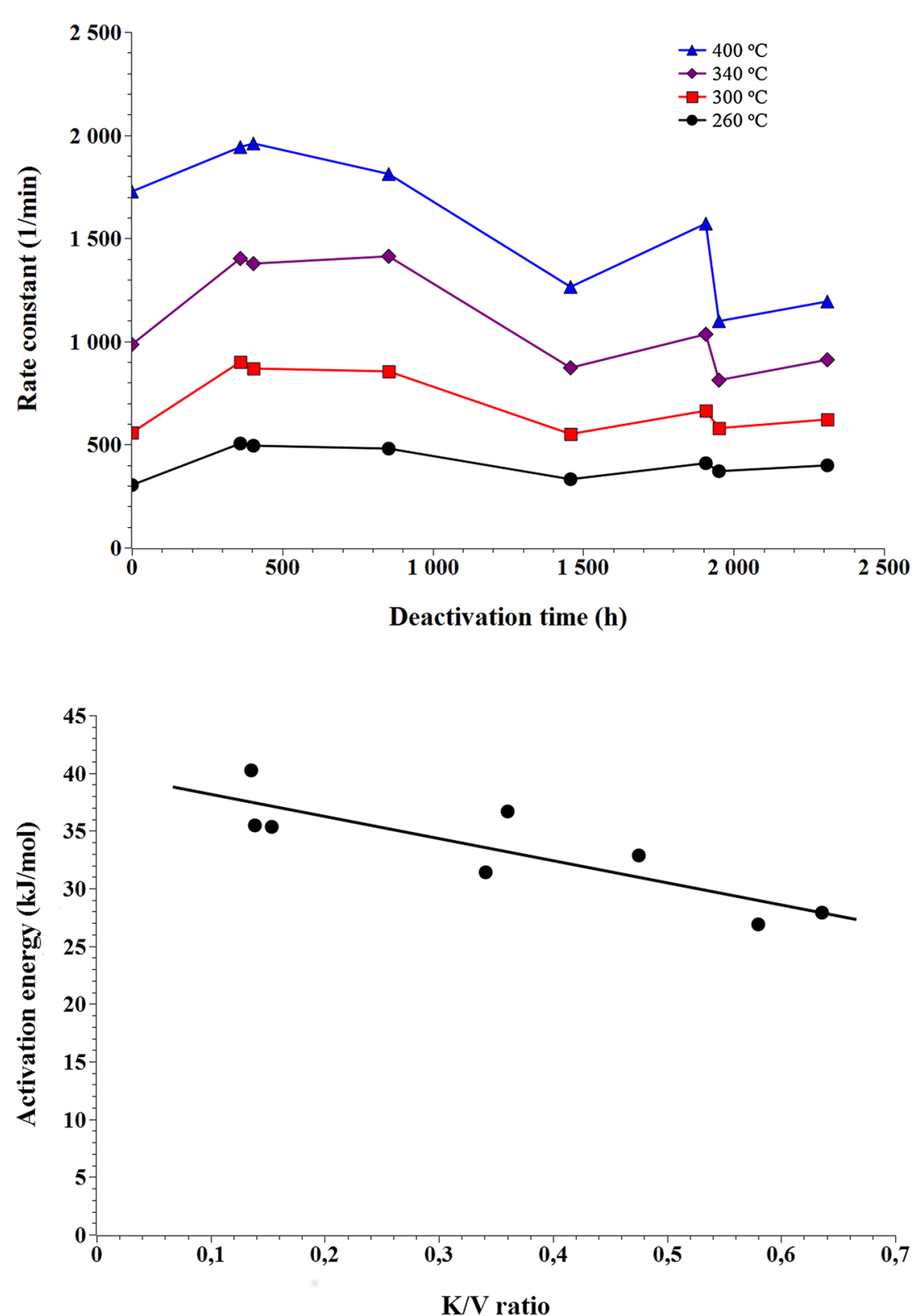

The activation energy decreases linearly with the exposure time, i.e., on the degree of contamination of the catalyst. In the present study, the activation energy decreased from $40 \mathrm{~kJ} / \mathrm{mol}$ in the fresh catalyst to $28 \mathrm{~kJ} / \mathrm{mol}$ in the catalyst exposed for $2311 \mathrm{~h}$, where the $\mathrm{K} / \mathrm{V}$ ratio was around 0.64 .

Pre-exponential factors were also determined in the temperature range 260 to $340{ }^{\circ} \mathrm{C}$ (from the same plots used in Fig. 11) and are shown in Fig. 12 for all catalysts.

Figure 12 shows that the pre-exponential factor decreased to very low values (around $1.6 \times 10^{5} 1 / \mathrm{min}$ ) after long exposure times.

The pre-exponential factor for the fresh catalyst is $2.65 \times 10^{6}(1 / \mathrm{min})$, while for the catalyst exposed for $1951 \mathrm{~h}$ it is about $1.63 \times 10^{5}$, i.e., a decrease of $94 \%$.

\subsubsection{Effect of Mass and Temperature Gradients}

In our experiments, the SCR reaction rate is limited by diffusion in the pores of the catalyst. We calculated the criteria for the absence of internal (criterion 7) and external (criterion 5) mass transport, according to Ramirez [23]. Table 7 presents the results for the fresh catalyst, where it can be seen that criterion 7 must be less than 0.15 , and criterion 5 less than 0.05 to ensure the absence of gradients.

At the lowest temperature, criterion 7 is just fulfilled. This means that the effectiveness factor for internal diffusion is just above 0.95 , and limitation due to internal diffusion is minimal. Criteria 7 and 5 are not met at any other temperature. Thus, both external mass transfer limitations and internal mass transfer limitations can be expected. These criteria 
Fig. 12 The dependency of the pre-exponential factor on the $\mathrm{K} / \mathrm{V}$ ratio for all the catalysts

Table 7 Estimation of mass transfer limitations according to Ramirez [23]

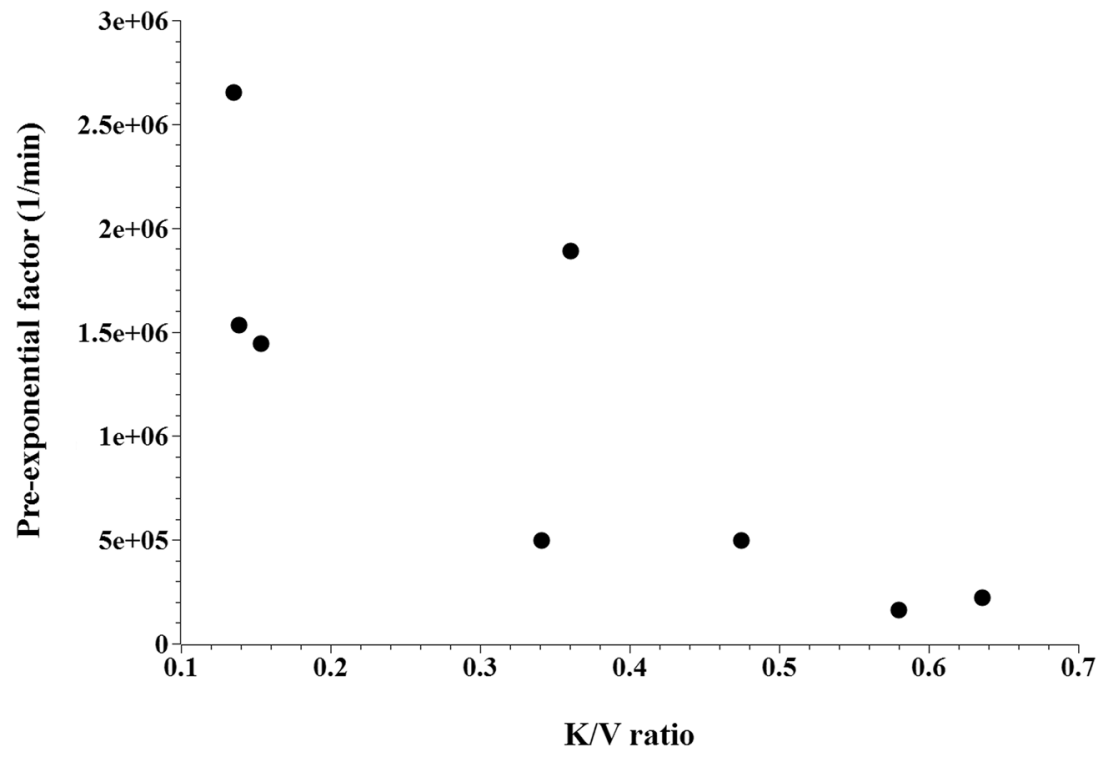

\begin{tabular}{llllll}
\hline $\mathrm{T}(\mathrm{K})$ & $\mathrm{rNO}_{\text {obs }}\left(\mathrm{mol} / \mathrm{cm}^{3}{ }_{\text {cat }} / \mathrm{s}\right)$ & $\mathrm{D}_{\text {effNO }}\left(\mathrm{cm}^{2} / \mathrm{s}\right)$ & $\mathrm{C}_{\text {NOin }}\left(\mathrm{mol} / \mathrm{cm}^{3}\right)$ & Criterion 7 & Criterion 5 \\
\hline 533 & $5.824 \times 10^{-8}$ & 0.473 & $1.414 \times 10^{-8}$ & 0.145 & 0.098 \\
553 & $7.009 \times 10^{-8}$ & 0.500 & $1.363 \times 10^{-8}$ & 0.171 & 0.116 \\
573 & $8.556 \times 10^{-8}$ & 0.532 & $1.315 \times 10^{-8}$ & 0.203 & 0.140 \\
593 & $1.004 \times 10^{-7}$ & 0.563 & $1.271 \times 10^{-8}$ & 0.233 & 0.162 \\
613 & $1.141 \times 10^{-7}$ & 0.590 & $1.229 \times 10^{-8}$ & 0.261 & 0.180 \\
633 & $1.235 \times 10^{-7}$ & 0.630 & $1.191 \times 10^{-8}$ & 0.274 & 0.192 \\
653 & $1.314 \times 10^{-7}$ & 0.660 & $1.154 \times 10^{-8}$ & 0.287 & 0.202 \\
673 & $1.368 \times 10^{-7}$ & 0.693 & $1.120 \times 10^{-8}$ & 0.293 & 0.211 \\
\hline
\end{tabular}

Criterion 7 Internal diffusion limitations are negligible when the criterion is $<0.15$, Criterion 5 External (film) diffusion limitations are negligible when the criterion is $<0.05$ have also been calculated for the catalyst exposed for $1951 \mathrm{~h}$. The values obtained were somewhat higher, so this sample will also be limited by mass transfer. All the other samples will be limited by external and internal mass transfer since their observed rates of NO reduction were higher.

The external and internal temperature gradients (calculations not shown) were small and would not have any significant effect on the results. The rate of the SCR reaction is so high that a temperature gradient of $6.3{ }^{\circ} \mathrm{C}$ can be expected along the reactor axis. The internal temperature gradient inside the catalyst wall is below $0.035{ }^{\circ} \mathrm{C}$, thus the catalyst is isothermal over its cross section, but not along its axis.

\section{Discussion}

In this study, a commercial $\mathrm{V}_{2} \mathrm{O}_{5} / \mathrm{WO}_{3} / \mathrm{TiO}_{2} \mathrm{SCR}$ monolith was subjected to long-term exposure to flue gas containing fly ash from a municipal waste incineration plant. Analysis of the composition of the fly ash showed the presence of $\mathrm{P}$,
Ti, Fe, Mg, Zn, Na, K, Al, S, Cl, Si and Ca. Unfortunately no $\mathrm{Pb}$ was detected in our fly ash sample but the deactivated catalyst contained $\mathrm{Pb}$. On the other hand Eigmy et al. [27] analysed fly ash from a waste incinerator using neutron activation and inductively-coupled- atomic emission spectroscopy (ICP-AES) for $\mathrm{Pb}$. They reported the following elemental contents (wt\%): $\mathrm{Cl}$ (23.2), K (10.9), Zn (10.4), Na (8.4), $\mathrm{Ca}$ (4.6), $\mathrm{Si}$ (3.8), $\mathrm{Pb}$ (2.7) and $\mathrm{Al}$ (2.1) (they did not analyse the $\mathrm{S}$ content). Some of the compounds they found were $\mathrm{NaCl}, \mathrm{K}_{2} \mathrm{ZnCl}_{4}, \mathrm{CaAl}_{4} \mathrm{O}_{7}, \mathrm{~K}_{4} \mathrm{PbO}_{4}$ and $\mathrm{CaSiO}_{3}$. The $\mathrm{Pb}$ was found to exist in the forms $\mathrm{Pb}, \mathrm{PbO}, \mathrm{PbCl}_{2}$ and $\mathrm{PbSO}_{4}$. Our analysis of the catalyst used/exposed for $1908 \mathrm{~h}$ (using SEM-EDAX) showed the same elements. The ash must have been subjected to temperatures much above $300{ }^{\circ} \mathrm{C}$ in the incinerator before reaching the catalyst. The presence of components in the ash that melt at $300{ }^{\circ} \mathrm{C}$ shows that salts precipitate from the hot flue gas when it cools down. The precipitated salts form aerosol particles in the flue gas, which are captured by the fly ash. Our analysis of the micropore volume and pore area distribution of the fly ash 
showed that the volume of pores below $30 \AA$ decrease above $300{ }^{\circ} \mathrm{C}$. We believe that the fusible compound in the fly ash may be $\mathrm{ZnCl}_{2}$ (melting point $290{ }^{\circ} \mathrm{C}$ ), and the decrease in the number of small pores of the fly ash is due to their being filled with molten $\mathrm{Zn}$ salts (i.e. $\mathrm{ZnCl}_{2}$, or molten $\mathrm{K}$ Zn double salts).

The surface area with $\left(65 \mathrm{~m}^{2} / \mathrm{g}\right.$ at $400{ }^{\circ} \mathrm{C}$ degassing temperature) and the pore structure of the fresh catalyst are in agreement similar catalysts [28]. The total pore volume and the micropore volume, 0.271 and $0.0028 \mathrm{~cm}^{3} / \mathrm{g}$ are also in agreement with similar catalysts.

The fresh catalyst was sintered at $400{ }^{\circ} \mathrm{C}$ in dry air in an oven for various amounts of time. The BET area decreased rapidly during the first $4 \mathrm{~h}$ from, 70 to $62 \mathrm{~m}^{2} / \mathrm{g}$. After some instability up to $72 \mathrm{~h}$, the BET area remains at $62 \mathrm{~m}^{2} / \mathrm{g}$ up to the final time at $288 \mathrm{~h}$ (Results not shown here). This change in area is quite unlike that we observed in a previous study at $20 \mathrm{wt} \% \mathrm{~V}_{2} \mathrm{O}_{5}$, [29], where the BET area followed the general power law expression (GPLE) [30]. The GPLE model for sintering is based on the differential equation: $\mathrm{dS} / \mathrm{dt}=-\mathrm{k} \times\left(\mathrm{S}-\mathrm{S}_{\mathrm{eq}}\right)^{\mathrm{n}}$. The surface area approaches a constant value, $S_{\text {eq }}$, at long times. The exponent $\mathrm{n}$ is usually 2 . A gradual decrease in the area with time was seen, especially in the presence of water [29]. The time in the deactivation unit does not affect the surface area to the same extent as the activity decrease. Therefore, deactivation is of a chemical nature.

The amount of $\mathrm{V}^{5+}$ deposited on the catalyst surface in the present study was $1.75 \mu \mathrm{mol} / \mathrm{m}^{2}$. This can be compared to $13 \mu \mathrm{mol} / \mathrm{m}^{2}$ for a monolayer catalyst [31]. The active vanadia sites are isolated $\mathrm{VO}_{4}$ units with one $\mathrm{V}=\mathrm{O}$ bond and three $\mathrm{V}-\mathrm{O}-\mathrm{Ti}$ bonds. The $\mathrm{WO}_{3}$ is a non-interacting additive and does not influence the structure of the vanadia species unless the content of vanadia is above one monolayer. Water has an effect at low temperatures, but not above $300{ }^{\circ} \mathrm{C}$ where the vanadia retains its structure.

The fly ash contains compounds that poison the catalyst, which accumulate on the outer surface and in the pore system. The most detrimental components are $\mathrm{K}$ and $\mathrm{Na}$, which directly neutralise the $\mathrm{V}-\mathrm{O}-\mathrm{H}$ groups, the sites on the catalyst for the adsorption of $\mathrm{NH}_{3}$, thus leading to rapid deactivation of the original sites. In parallel to this deactivation, we have formation of new Brønsted acid sites from sulphate groups, as described in [7]. The ammonia adsorbed on these sites serves as a depot of ammonia needed for the reduction of NO.

Chemical analysis by SEM-EDAX showed that the fresh catalyst contained the components expected in a commercial SCR catalyst. The accumulation of poisons on the outer surface of the catalyst used for $1908 \mathrm{~h}$, was revealed using EDAX. The contents of $\mathrm{Na}, \mathrm{K}$ and $\mathrm{Zn}$ increased linearly with exposure time. Most of the poisons were found on the outer surface, and $\mathrm{Zn}, \mathrm{Cl}$ and $\mathrm{Pb}$ did not penetrate into the bulk of the catalyst. More $\mathrm{S}$ was present in the bulk of the used catalyst than in the fresh one. The S/Ti ratio was 0.0275 in the bulk of the catalyst used for $1908 \mathrm{~h}$, compared to 0.0163 in the fresh catalyst, and is an effect of creation of new sulphate groups on the surface. The SEM analysis of the catalyst used for $1908 \mathrm{~h}$ showed that compounds covered two different areas on the surface to much different degrees. The contents of elements in the interior of the used catalyst and the bulk of the fresh catalyst were very similar. The catalyst used for $2311 \mathrm{~h}$ had a surprisingly low content of both $\mathrm{Pb}(0.16 \mathrm{wt} \%)$ and $\mathrm{Ca}(0.04 \mathrm{wt} \%)$. This could be explained by some of the $\mathrm{Ca}$ and $\mathrm{Pb}$ deposited as a surface layer on the outside of the monolith falling off before analysis, or if the flow distribution in the deactivating unit was such that this position did not have as high a flow as the others. This particular sample was at the same position in the deactivating unit through all $2311 \mathrm{~h}$ of deactivation.

The results for $\mathrm{Na}$ are more scattered than those for $\mathrm{K}$ and $\mathrm{Zn}$, probably because of the higher diversity of food waste than other types of waste that are mixed for combustion. However, the deposition rates are constant over time (Fig. 7) so the long-term composition of the feed is constant. This also agrees well with verbal information from the personnel at the plant that the fuel (waste from different origins) is mixed to obtain a uniform composition to avoid problems during combustion.

The activity changed (apparent 1 st order rate constant) with time-on-stream. The rate constant first increased by $46 \%$ at $853 \mathrm{~h}$, and then decreases by $17 \%$ at $1951 \mathrm{~h}$, compared to the fresh sample. At longer exposure times, the rate constant is almost constant, being $91 \%$ of the value for the fresh sample after $2311 \mathrm{~h}$ of use. The rate constant at $1908 \mathrm{~h}$ of use is higher than expected. The low values of both $\mathrm{K}$ and $\mathrm{Na}$ in this sample can explain this result. We observed a trend of decreasing activation energy with increasing degree of contamination. The activation energy decreased from $40 \mathrm{~kJ} / \mathrm{mol}$ for the fresh catalyst, to $28 \mathrm{~kJ} / \mathrm{mol}$ in that used for the longest time. The pre-exponential factor decreased by $92 \%$ for the most deactivated sample. Thus, this method of analysis, using pre-exponential factors instead of rate constants, gives a clearer picture of the deactivating effect. Others $[1,2]$ have also observed similar trends.

It should be noted that the deactivating effects measured in this study are the combined effects of $\mathrm{K}, \mathrm{Na}$ and possibly $\mathrm{Zn}$, and it is not possible to distinguish the effect of one component only from our data. In this study it was found that the apparent activation energy decreased with increasing deactivation. We have interpreted this as being the result of an increase in diffusion resistance. If the catalyst is deactivated by deposition of poisons first on the outer surface, the poisons have to diffuse into the catalyst. This should result in a gradient of poisons from the outer surface towards the centre of the catalyst. The 
catalyst activity will mirror this gradient; low activity at the outer surface and gradually increasing activity in the central parts. This means that the reactants have to diffuse through a gradually growing porous layer of more or less inert material. The same could apply when fouling the outer surface with a porous layer of inert, small particles.

Tokarz [4] studied a $\mathrm{V}_{2} \mathrm{O}_{5} / \mathrm{TiO}_{2} / \mathrm{SiO}_{2}$ catalyst with a surface area of about $200 \mathrm{~m}^{2} / \mathrm{g}$ and a pore volume of $1 \mathrm{~cm}^{3} / \mathrm{g}$ for applications in flue gas cleaning in waste incineration, both in the lab and in the plant. The particle size used in the lab studies was $60-80 \mu \mathrm{m}$. An impregnated catalyst was used to study the effect of each element on 1 and $3 \mathrm{wt} \%$ basis of the added element. Their values of the ratio of the rate constant for the catalyst in question to the rate constant for the fresh catalyst $\left(\mathrm{k} / \mathrm{k}_{\text {fresh }}\right)$ were 0.822 for $\mathrm{Fe}, 0.708$ for $\mathrm{Zn}, 0.657$ for $\mathrm{Ca}, 0.473$ for $\mathrm{Na}$ and 0.144 for $\mathrm{K}$, at $180^{\circ} \mathrm{C}$ and $3 \mathrm{wt} \%$ of the metals. This gives an indication of the degree of poisoning resulting from the elements studied. The metal contents determined in this study at $400{ }^{\circ} \mathrm{C}$ were: $0.36 \mathrm{wt} \%$ for $\mathrm{Zn}, 0.26 \mathrm{wt} \%$ for $\mathrm{K}$ and $0.2 \mathrm{wt} \%$ for $\mathrm{Na}$ after $2311 \mathrm{~h}$ deactivation. Therefore, the effects should be smaller by a factor of at least 10 . However, it is difficult to compare the values of activities at two such different temperatures.

Kröcher and Elsener [32] studied compounds present in catalysts used in treatment of exhausts from diesel engines and their effect on the catalytic activity. They found similar compounds to those in the present study, so their findings are discussed here, despite the fact that the application is different. They reported a linear decrease in the rate constant with the ratio of potassium to vanadium to the value 0.1 , where the decrease in activity was about $80 \%$. Thereafter, the decrease was smaller, but at the ratio of potassium to vanadium $(K / V)=0.2$ the decrease in activity was $98 \%$. We also observed a similar levelling-off of the effect of poisons at high metal to vanadium ratios.

Larsson et al. [33] studied the effects of impregnation and aerosol deposition on activity. When $\mathrm{KCl}$ was impregnated into the catalyst to a concentration of $0.2 \mathrm{wt} \%$ (fresh catalyst $0.05 \%$ ), the decrease in activity at $300{ }^{\circ} \mathrm{C}$ was $22.4 \%$. Aerosol deposition led to a deactivation of only $6.7 \%$. When using $\mathrm{ZnCl}_{2}$ the effects were $24.1 \%$ for impregnation and $32.4 \%$ for aerosol deposition. Aerosol deposition with $\mathrm{K}_{2} \mathrm{SO}_{4}$ showed lower values than with $\mathrm{ZnCl}_{2}$, while impregnation with $\mathrm{K}_{2} \mathrm{SO}_{4}$ had the same effect as with $\mathrm{ZnCl}_{2}$ showing that aerosol particles do not enter the catalyst pores. The activation energies reported for the fresh and the particle-deposited samples were constant, but decreased with contamination in the impregnated samples, to $12.2 \mathrm{~kJ} / \mathrm{mol}$, for the sample with the lowest amount of $\mathrm{K}$. Their reported activation energies were so low that they might be strongly effected by diffusion processes, and some of the poisoning effects could thus be disguised. Nonetheless, this comparison is interesting as we believe that the deactivation process in in the present study was of the particle deposition type.

It is common to study the catalytic activity as a function of degree of coverage of the catalyst's active sites by poisons. Results are usually given for only one poison at a time. Tang et al. [34] showed that $\mathrm{Na}$ deactivates a $\mathrm{V}_{2} \mathrm{O}_{5} / \mathrm{TiO}_{2}$ catalyst. The rate constant measured at $310^{\circ} \mathrm{C}$ decreased from 97.1 to $35.0\left(\mathrm{~cm}^{3} / \mathrm{g} / \mathrm{s}\right)$, i.e. by $64 \%$, when the $\mathrm{Na} / \mathrm{V}$ molar ratio increased from 0 to 0.2 . Deng et al. [35] have studied the effects of the introduction of alkali during entrained-flow combustion. We believe that comparison with their results could be interesting as the mode of introduction of the poison is similar to ours. After $5 \mathrm{~h}$ exposure to $\mathrm{KCl}$, the value of $\mathrm{k} / \mathrm{k}_{\text {fresh }}$ was 0.35 (measured at $400{ }^{\circ} \mathrm{C}$ ). The content of $\mathrm{K}$ was then $0.0659 \mathrm{wt} \%$. This is at a value of wt $\% \mathrm{~K}$ where we observed an increased rate of reaction as a result of activation by new sulphate groups on the surface. During the first $500 \mathrm{~h}$ on-stream our values of $\left(\mathrm{k} / \mathrm{k}_{\text {fresh }}\right)$ increased by a factor of 1.4 , at $340{ }^{\circ} \mathrm{C}$, instead of decreasing. In the presence of $\mathrm{SO}_{2}$ and $\mathrm{O}_{2}, \mathrm{SO}_{3}$ is formed at the vanadia sites at a low reaction rate [36]. This takes place in the deactivation unit in the current study, at $230{ }^{\circ} \mathrm{C}$, where the gas contained 50 to $200 \mathrm{ppm} \mathrm{SO}_{2}, 2 \% \mathrm{O}_{2}, 45 \mathrm{ppm} \mathrm{NO}, 25 \mathrm{ppm} \mathrm{NH}_{3}$ as well as nitrogen, water and fly ash. Under these conditions, sulphate species are formed that are bound to the $\mathrm{TiO}_{2}$ support, increasing the Brønsted acidity of the catalyst.

$\mathrm{Yu}$ et al. [37] investigated fresh and poisoned (by $\mathrm{KNO}_{3}$ impregnation) commercial $\mathrm{V}_{2} \mathrm{O}_{5}-\mathrm{WO}_{3} / \mathrm{TiO}_{2}$ honeycomb catalysts, and obtained similar results. They reported an increase in the conversion from 40 to $70 \%$ by the addition of $1500 \mathrm{ppm} \mathrm{SO}_{2}$ to the gas flowing over a K-poisoned $(\mathrm{K} / \mathrm{V}=0.77)$ catalyst. Chen and Yang [38] also reported a similar increase in conversion using $\mathrm{SO}_{2}$ for catalysts deactivated by $\mathrm{Ca}$ and $\mathrm{Li}$. Their reported rate constants were $0.4 \mathrm{~cm}^{3} / \mathrm{g} / \mathrm{s}$ for $\mathrm{K} / \mathrm{V}=0.53$ and $10 \mathrm{~cm}^{3} / \mathrm{g} / \mathrm{s}$ for the fresh catalyst, at $300{ }^{\circ} \mathrm{C}$. Our values were 4.96 and $4.95 \mathrm{~cm}^{3} / \mathrm{g} / \mathrm{s}$ at $\mathrm{K} / \mathrm{V}=0.58$. This demonstrates the effect of activation by surface sulphation. Klimczak et al. [39] studied the deactivation of a $\mathrm{V}_{2} \mathrm{O}_{5}-\mathrm{WO}_{3} / \mathrm{TiO}_{2}$ catalyst using both impregnation and aerosol exposure. The deactivating effect was greater at temperatures above $350{ }^{\circ} \mathrm{C}$, as was observed in the present study. $\mathrm{KNO}_{3}$ aerosols caused a decrease in the conversion of NO from 62 to $17 \%$ at $350{ }^{\circ} \mathrm{C}$. The corresponding values for aerosols of $\mathrm{NaNO}_{3}$ and $\mathrm{CaNO}_{3}$ were to 20 and $49 \%$, respectively. They also found good correlations between the experimental activity and that calculated with contributions from single poisons, as well as interactions between several poisons. Furthermore, they demonstrated the positive effect of sulphur on the activity of poisoned catalysts, as in the present study.

No correlation of activity with concentration of poisons were observed for $\mathrm{Fe}, \mathrm{Pb}$ and $\mathrm{Ca}$. $\mathrm{The} \mathrm{Pb} / \mathrm{V}$ ratio in the fresh catalyst was only $3.7 \%$ of the K/V ratio. Thus, only the effect 
is foreseen to be largest for the alkali metals in the fresh material at least. Even at higher degrees of deactivation, the $\mathrm{K} / \mathrm{V}$ ratios are about four times higher than the $\mathrm{Pb} / \mathrm{V}$ ratios. $\mathrm{The} \mathrm{Ca} / \mathrm{V}$ ratio ranged from 0.1 to 2.0 (probably only on the surface meaning a low effect on the activity). The Fe coverage ranged from 0.15 to 0.25 and was fairly constant over time. For comparison, the $\mathrm{K}$ coverage varied from 0.135 to 0.636 .

Kamata [3] impregnated a commercial catalyst of the same type as in the present study containing $1 \% \mathrm{~V}_{2} \mathrm{O}_{5}$ with up to $2 \mathrm{wt} \% \mathrm{~K}$ in the form of $\mathrm{KNO}_{3}$. They used small particle sizes of 0.10 to $0.18 \mathrm{~mm}$. We calculated the apparent values of the activation energy and pre-exponential factor from their data. The result was an activation energy of $76.7 \mathrm{~kJ} / \mathrm{mol}$ for the fresh catalyst and $3.81 \times 10^{11}(1 / \mathrm{min})$ for the pre-exponential factor. At a degree of poisoning of $\mathrm{K} / \mathrm{V}=0.2$ the activation energy was almost unchanged, while the pre-exponential factor was $2.42 \times 10^{11}$ (a decrease of $36 \%$ ). We obtained values of the activation energy and the pre-exponential factor of $40.2 \mathrm{~kJ} / \mathrm{mol}$ and $2.65 \times 10^{6}(1 /$ $\mathrm{min}$ ), respectively, for the fresh catalyst. When $\mathrm{K} / \mathrm{V}$ was 0.2 we obtained values of $36.3 \mathrm{~kJ} / \mathrm{mol}$ for the activation energy and $1.68 \times 10^{6}$ for the pre-exponential factor. The decrease in the pre-exponential factor is $37 \%$ for our values, which is in excellent agreement with the results of Kamata. At $260{ }^{\circ} \mathrm{C}$, the rate constant for the fresh catalyst calculated from data given by Kamata was $1.16 \times 10^{4}(1 / \mathrm{min})$, whereas our value was 320 , i.e. a factor of 36 lower. At $400{ }^{\circ} \mathrm{C}$ the corresponding values were $1.39 \times 10^{5}$ (Kamata) and $1.72 \times 10^{3}$ (the present study), i.e. they differ by a factor of 81 . This indicates much greater limitation by internal diffusion in our study than in that of Kamata.

In the case of potassium, Chen and Yang [38] reported a $34.6 \%$ decrease in the rate constant at $300{ }^{\circ} \mathrm{C}$, at a $\mathrm{K} / \mathrm{V}$ coverage of 0.2 . We found a $48 \%$ decrease in the pre-exponential factor at $\mathrm{K} / \mathrm{V}=0.2$ for the fitted values. It should be noted that our results are the combined effect of several poisons, and effect will thus be greater than for a single poison.

Lisi et al. studied the combined deactivating effects of alkali metals and $\mathrm{HCl}$ [40]. For a catalyst with $1.88 \mathrm{wt} \% \mathrm{~V}$ they observed an exponential decrease in the pre-exponential factor, from 85.5 for the fresh material, to $36.8 \mathrm{~L}(\mathrm{~h} / \mathrm{g})$, at $0.18 \mathrm{wt} \% \mathrm{Na}$. For $\mathrm{K}$ the value of the pre-exponential factor at $0.3 \mathrm{wt} \%$ was $35.9 \mathrm{~L}(\mathrm{~h} / \mathrm{g})$. In their experiments, the activation energy was constant at $58.6 \mathrm{~kJ} / \mathrm{mol}$. The wt\% used for $\mathrm{Na}$ and $\mathrm{K}$ should represent equal molar ratios for $\mathrm{Me} / \mathrm{V}$. The degree of deactivation was reported to be almost identical at $0.18 \mathrm{wt} \% \mathrm{Na}$ and $0.3 \mathrm{wt} \% \mathrm{~K}$. A levelling off of the factor was seen at higher degrees of poisoning. These results are similar to those obtained in the present study.

Mass gradients limit the rate of reaction, but not to a very high degree. The apparent activation energy of $40 \mathrm{~kJ} / \mathrm{mol}$ for the fresh catalysts indicates mass transfer limitations since the intrinsic activation energy is around $85 \mathrm{~kJ} / \mathrm{mol}$. We have found one other paper [41] reporting the gradients in a $3.45 \% \mathrm{~V}_{2} \mathrm{O}_{5} / \mathrm{TiO}_{2}$ catalyst measured at $300{ }^{\circ} \mathrm{C}$. The concentration of $\mathrm{NO}$ at the centre of the fresh catalyst was reported to be $20 \%$ of the value at the monolith wall (internal gradient, wall thickness of $0.38 \mathrm{~mm}$ ). When it was poisoned with $0.85 \mathrm{wt} \% \mathrm{~K}_{2} \mathrm{O}$ the concentration of $\mathrm{NO}$ at the centre increased to $83 \%$ of its surface value. The value of $\mathrm{K}_{2} \mathrm{O}$ used in the present study was $0.26 \mathrm{wt} \%$ at the highest degree of poisoning so the effect should be smaller. This agrees with our conclusions, that our experiments are limited by internal as well as external mass transfer. Since the gas flows only inside the monolith in our experiments, we used the whole wall thickness as the characteristic length, which could cause some errors in the calculations. We have found no publications on the mass transfer conditions in one-sided flow in a monolith.

\section{Conclusions}

It is clear from the results of this study that there is no significant change in the mesopore system of the SCR catalyst as a result of the accumulation of poisons. However, some poisons cause the volume and area of the micropores to decrease significantly. Since the reaction rate is not strongly affected by internal diffusion limitations, all parts of the catalyst will contribute to the activity. As the changes in surface area and pore structure are minimal, the effects seen on the activity are mainly caused by chemical deactivation. Many poisons were accumulated in the deactivated catalysts, which will decrease the activity; the strongest being $\mathrm{K}$ and $\mathrm{Na}$, but Zn will also decrease the activity. No such effect was observed for $\mathrm{Pb}, \mathrm{Fe}$ or $\mathrm{Ca}$. The high content of $\mathrm{Cl}$ in the fly ash could contribute significantly to the deactivation process, but was not studied separately in this work.

The results of this investigation show an increase in catalytic activity due to $\mathrm{SO}_{2}$ (as sulphates) up to $853 \mathrm{~h}$ onstream, at which the maximum activity is reached. This is an important result, since on-stream activation actually prolongs the lifetime of the catalyst. Thereafter, a rapid decrease is observed in the contents of $\mathrm{Na}$ and $\mathrm{K}$ especially. $\mathrm{Zn}$ also lowers the activity of the catalyst, but the effect starts at higher coverage of the vanadium atoms.

The results presented here are important, not only for waste incineration, but also for incineration in general, since they show how deactivation proceeds when the catalyst is deactivated by fly ash components.

Acknowledgements We wish to thank Johan Janner who measured the rate of reduction $\mathrm{NO}_{\mathrm{x}}$. Birgitta Lindén helped us with the nitrogen adsorption measurements and the SEM analysis. The Swedish waste incineration plant is acknowledged for allowing us to use their facilities to expose the catalyst samples. 
Open Access This article is distributed under the terms of the Creative Commons Attribution 4.0 International License (http://creativecommons.org/licenses/by/4.0/), which permits unrestricted use, distribution, and reproduction in any medium, provided you give appropriate credit to the original author(s) and the source, provide a link to the Creative Commons license, and indicate if changes were made.

\section{References}

1. van Caneghem J, de Greef J, Block C, Vandecasteele C (2016) J Clean Prod 112:4452

2. Peng Y, Li J, Si W, Luo J, Wang Y, Fu J, Li X, Crittenden J, Hao J (2015) Appl Catal Environ 169:195

3. Kamata H, Takahashi K, Odenbrand CUI (1999) J Mol Catal A 139(2-3):189

4. Tokarz M, Järås S, Persson B (1991) Catalyst deactivation 1991. Elsevier, Amsterdam

5. Khodayari R, Odenbrand CUI (2001) Appl Catal B 30:87

6. Khodayari R, Odenbrand CUI (1998) Ind Eng Chem Res 37(4):1196

7. Brandin JGM, Odenbrand CUI (2017) Top Catal. doi:10.1007/ s11244-017-0816-y

8. Benassi L, Pasquali M, Zanoletti A, Dalipi R, Borgese L, Depero LE, Vasura I, Quina MJ, Bontempi E (2016) ASC Sustain Chem Eng 4:5561

9. Purgar A, Winter F, Blasenbauer D, Hartmann S, Fellner J, Lederer J, Rechberger H (2016) Fuel Process Technol 141:243

10. Gallastegi-Villa M, Aranzabal A, Gonzalez-Marcos JA, GonzalezVelasco JR (2017) Appl Catal B, 205:310

11. Jung H, Park E, Kim M, Jurng J (2017) Waste Manag 61:283

12. Li J, Peng Y, Chang H, Li X, Crittenden JC, Hao J (2016) Front Environ Sci Eng 10(3):413

13. Wu X, Yu W, Si Z, Weng D (2013) Front Environ Sci Eng $7(3): 420$

14. Chen L, Li J, Ge M (2011) Chem Eng J 170:531

15. Tang F, Xu B, Shi H, Qui J, Fan Y (2010) Appl Catal B 94:71

16. Nicosia D, Elsener M, Kröcher O, Jansohn P (2007) Top Catal $42-43: 333$
17. Yu W, Wu X, Si Z, Weng D (2013) Appl Surf Sci 283:209

18. Lei T, Li Q, Chen S, Liu Z, Liu Q (2016) Chem Eng J 296:1

19. Wey M-Y, Ou W-Y, Liu Z-S, Tseng H-H, Yang W-Y, Chiang B-C (2001) J Hazard Mater B 82:247

20. Yu Y, Meng X, Chen J, Yin L, Qiu T, He C (2016) Environ Technol 37(7):828

21. Zheng Y, Degn Jensen A, Johnsson JE (2004) Ind Eng Chem Res 43:941

22. Tronconi E (1997) Catal Today $34: 421$

23. Perez-Ramirez J, Berger RJ, Mul G, Kapteijn F, Moulijn JA (2000) Catal Today 60(1-2):93

24. Brunnauer S, Emmett PH, Teller E (1938) J Am Chem Soc 60:309

25. Barett EP, Joyner LG, Halenda PP (1951) J Am Chem Soc 73:373

26. Harkins WD, Jura G (1944) J Am Chem Soc 66(6):919

27. Eighmy TT, Eusden JD, Krzanowski JE, Domingo DS, Stämpfli D, Martin JR, Erickson PM (1995) Environ Sci Technol 29:629

28. Nicosia D, Czekaj I, Kröcher O (2008) Appl Catal B 77:2228

29. Odenbrand CUI (2008) Chem Eng Res Des 86:663

30. Fuentes GA, Gamas ED (1991) Catalyst deactivation. Elsevier, Amsterdam

31. Dunn JP, Stenger HG Jr, Wachs IE (1999) Catal Today 51:301

32. Kröcher O, Elsener M (2008) Appl Catal B 75:215

33. Larsson YA-C, Einvall J, Andersson A, Sanati M (2006) Energy Fuels 20:1398

34. Tang F, Xu B, Shi H, Qiu J, Fan Y (2010) Appl Catal B 94:71

35. Deng L, Liu X, Cao P, Zhao Y, Du Y, Wang C (2016) J Energy Inst. doi:10.1016/j.joei.2016.07.003

36. Dunn JP, Koppula PR, Stenger HG, Wachs IE (1998) Appl Catal B 19:103

37. Yu Y, Wang J, Chen J, Meng X, Chen Y, He C (2014) Ind Eng Chem Res 53:16229

38. Chen JP, Yang RT (1990) J Catal 125:411

39. Klimczak M, Kern P, Heinzelmann T, Lucas M, Claus P (2010) Appl Catal B 95:39

40. Lisi L, Lasorella G, Mallogi S, Russo G (2004) Appl Catal B 50:251

41. Chen JP, Buzanowski MA, Yang RT, Cichanowicz JE (1990) J Air Waste Manag Assoc 40:1403 